\title{
On the Tacticity of Polynorbornenes with 5,6-endo Pendant Groups That Contain Substituted Aryl Chromophores
}

\author{
Wei-Yu Lin, ${ }^{[a]}$ Hsian-Wen Wang, ${ }^{[a]}$ Zhi-Chang Liu, ${ }^{[b]}$ Jun Xu ${ }^{[c]}$ Chih-Wei Chen, ${ }^{[a]}$ \\ Yun-Chin Yang ${ }^{[\mathrm{a}]}$ Shou-Ling Huang, ${ }^{[\mathrm{a}]}$ Hsiao-Ching Yang ${ }^{[\mathrm{d}]}$ and Tien-Yau Luh ${ }^{*[\mathrm{a}]}$ \\ In memory of Yoshihiko Ito
}

\begin{abstract}
Two dimers and a series of polymers with 5,6-endo pendant aryl groups that contain different substituents at the para positions were synthesized. The conformation and stereochemistry of the dimers and polymers were determined by nonlinear optical analysis (EFISH) as well as $\mathrm{UV} / \mathrm{Vis}$ and ${ }^{13} \mathrm{C}$ NMR spectroscopy. The chemical shifts of $\mathrm{C} 7$ for the polymers appeared as two peaks in the ${ }^{13} \mathrm{CNMR}$
\end{abstract}

spectra when the substituents are electron-withdrawing groups. The percentage decrease in the relative extinction coefficient of the polymers, $\varepsilon_{\mathrm{d}}$, was linearly related to the Hammett constant $\sigma$. Polynorbornenes with electron-with-

Keywords: chromophores $\cdot$ pendant groups • polynorbornenes • ringopening polymerization $\cdot$ tacticity drawing substituents may adopt isotactic stereochemistry with all pendant groups aligned in one direction. The nature of the interactions between neighboring chromophores may be one of the most important factors in directing the stereoregularity and conformation of these polymers. The corresponding polymers derived from the exo isomers appeared to be less stereoregular.

\section{Introduction}

We recently reported an unprecedented approach for the synthesis of DNA-like double-stranded polymer $\mathbf{2}$ by Grubbs I catalyst (1)-promoted ring-opening metathesis polymerization (ROMP) of bisnorbornene derivative $\mathbf{3}$ (Scheme 1). ${ }^{[1]}$ The key to the success of this strategy lies in

[a] W.-Y. Lin, H.-W. Wang, C.-W. Chen, Y.-C. Yang, S.-L. Huang, Prof. T.-Y. Luh

Department of Chemistry, National Taiwan University

Taipei 106 (Taiwan)

Fax: + (886)2-2364-4971

E-mail: tyluh@ntu.edu.tw

[b] Z.-C. Liu

Shanghai Institute of Organic Chemistry

Chinese Academy of Sciences

Shanghai 200032 (China)

[c] J. Xu

Department of Chemistry

University of Science and Technology of China

Hefei, Anhui 230026 (China)

[d] Prof. H.-C. Yang

Department of Chemistry

Fu Jen Catholic University Hsinchuang, Taipei 24205 (Taiwan)

Supporting information for this article is available on the WWW under http://www.chemasianj.org or from the author. the rigid rodlike structure and stereochemical homogeneity of the polymer. It has been shown that the single-stranded polynorbornenes 4 with dipolar pendant groups at the C5 and C6 positions ${ }^{[2]}$ may adopt rigid rod structures. ${ }^{[3]}$ The stereochemistry of simple polynorbornenes has been extensively examined, and it appears that the nature of the catalyst and the structure of the monomeric norbornenes may influence the tacticity and the double-bond configurations of the polymers. ${ }^{[4-11]}$ To illustrate this, molybdenum-catalyzed ROMP of norbornenes gives mainly cis double bonds and isotactic selectivity. ${ }^{[7]}$ Recently, ROMPs of norbornadiene diester and exo,exo-2,3-dicarbomethoxy-5-norbornene with a ruthenium catalyst reportedly gave isotactic polymers with mainly trans double bonds. ${ }^{[8]}$ It has been shown that catalyst 1 yields predominantly trans double bonds in polynorbornenes. ${ }^{[9]}$ However, the tacticity of the polymers varies with substrate ${ }^{[4-11]}{ }^{13} \mathrm{C}$ NMR spectra have been widely used for the elucidation of the tacticity of these polymers. ${ }^{[10]}$ Thus, polymer 4 was shown to assume mainly isotactic stereochemistry, ${ }^{[8]}$ whereas $\mathbf{5}$ is atactic. ${ }^{[11]}$ In a preliminary communication, we showed that $\mathbf{6}$ exhibits molecule-dependent nonlinear optical $\beta_{\text {o }}$ values, ${ }^{[3]}$ which may imply that $\mathbf{6}$ may adopt homogeneous stereochemistry and conformation. Although $\mathbf{5}$ and $\mathbf{6}$ are structurally similar with pendant endo nitrogen heterocycles, the imide ring in $\mathbf{5}$ and the pyrrolidine moiety in $\mathbf{6}$ may behave differently under these ruthenium- 


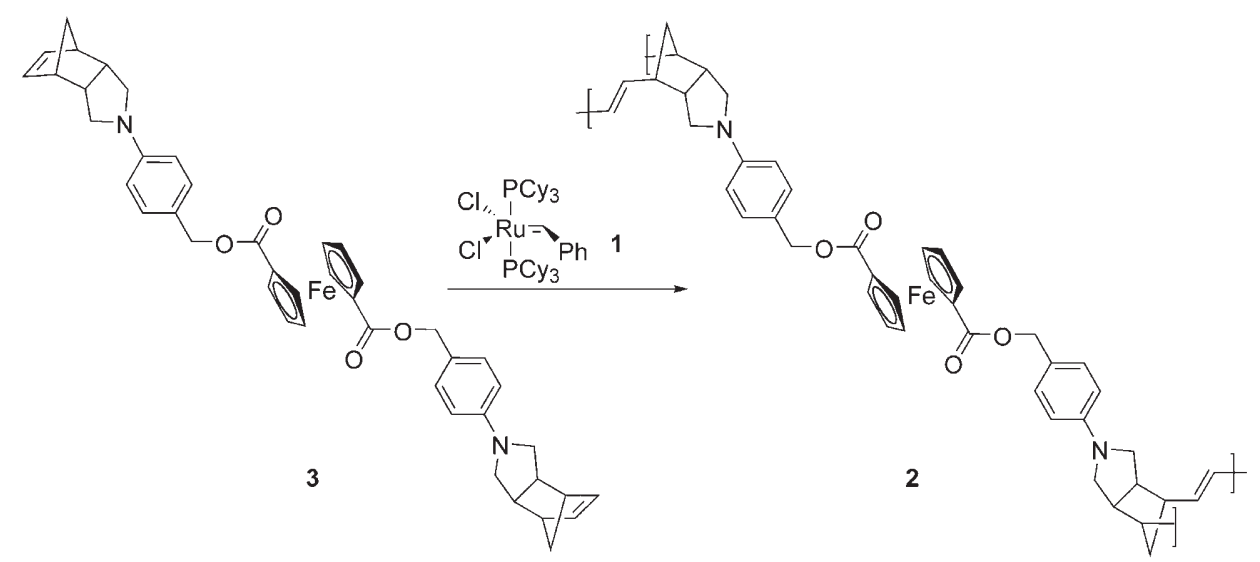

Scheme 1. ROMP of $\mathbf{3}$ to give double-stranded polymer 2 . Cy= cyclohexyl.

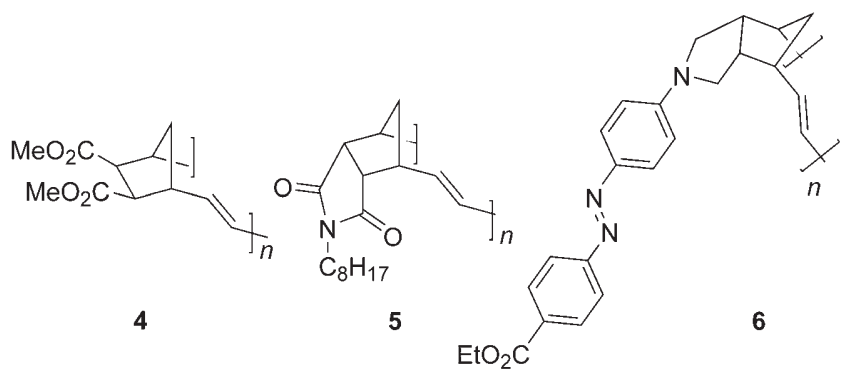
to 9 . ROMP of 9 followed by hydrolysis and esterification yields the corresponding complementary polymer $\mathbf{1 0}$ with an isotactic structure (Scheme 2). ${ }^{[12]}$ This finding indicates that polynorbornenes such as $\mathbf{7}$ should adopt homogeneous tacticity. We now report a systematic investigation into the tacticity of $\mathbf{6}$ and its related polymers, which have a range of different aryl pendant groups. catalyzed conditions. Furthermore, the presence of the $N$ aryl pendant groups in $\mathbf{6}$ may be an important factor because they may interact with the neighboring aryl pendant group. It is envisaged that such interaction may depend on the nature of the aromatic rings. aryl pendant groups may teractions. found that single-stranded polymer 7 can serve as a template to accommodate monomeric norbornene moiety $\mathbf{8}$, leading Hence, the substituent on

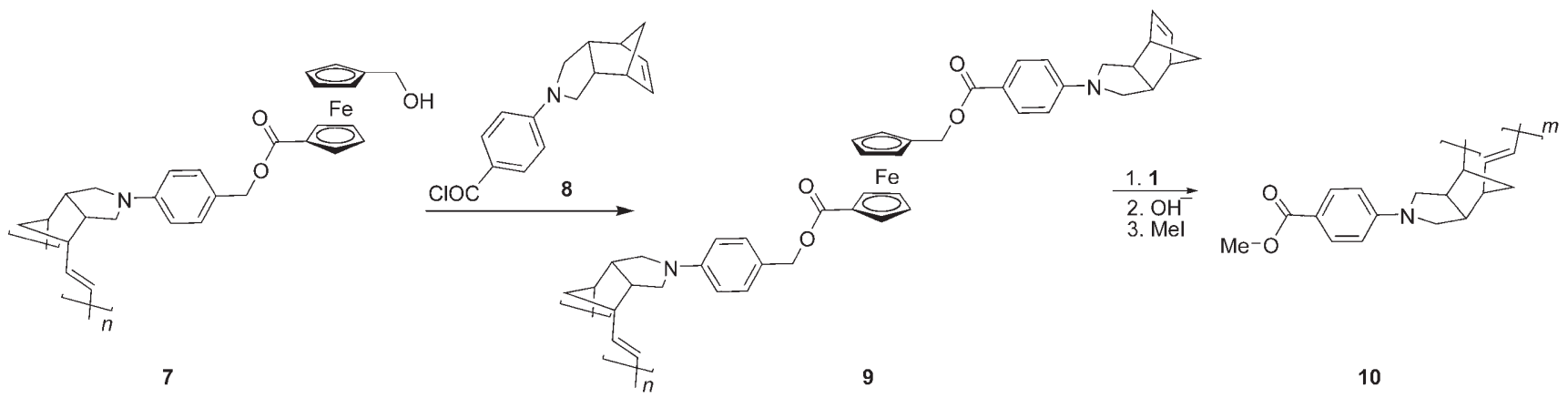

Scheme 2. Replication of $\mathbf{7}$ to give complementary polymer $\mathbf{1 0}$.

\begin{abstract}
Chinese:
我們利用開環複分解聚合反應, 合成了含5,6-endo具不同 取代基苯基的䀣掛基團降冰片烯的二聚物和一系列的聚合物, 透過非線性光學性質（EFISH），吸收光譜，以及碳譜確認其立 體化學。從聚合物的碳譜中可以看出，當苯環有拉電子取代基 時, C7的信號出現兩個峰。聚合物的相對消光係數減少的百分 數 $\varepsilon$ 與Hammett常數 $o$ 成線性關係。含有吸電子取代基的降冰 片烯聚合物可能採取全同立構的立體化學，且所有懸掛基團朝 向同一方向。相鄰發色團之間的相互作用，可能是導致聚合物 採取這種立體規整性的主要因素。
\end{abstract}




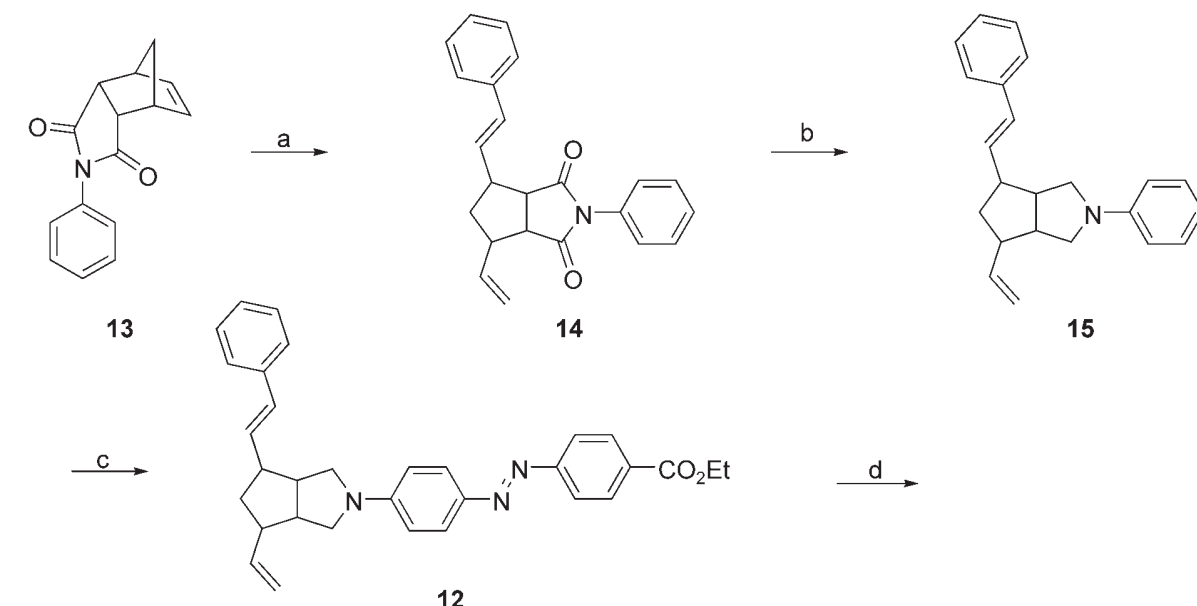

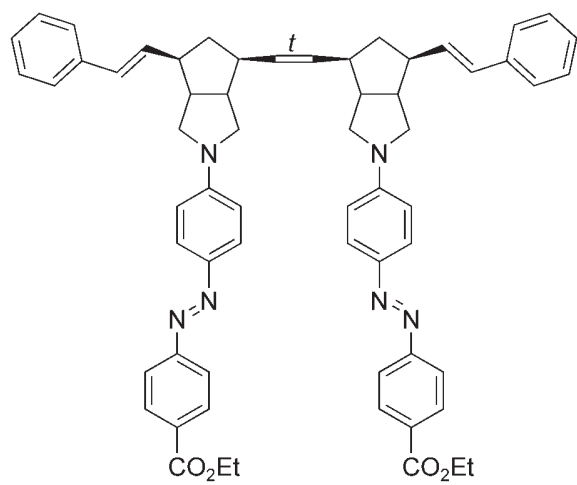

$11 \mathrm{a}$

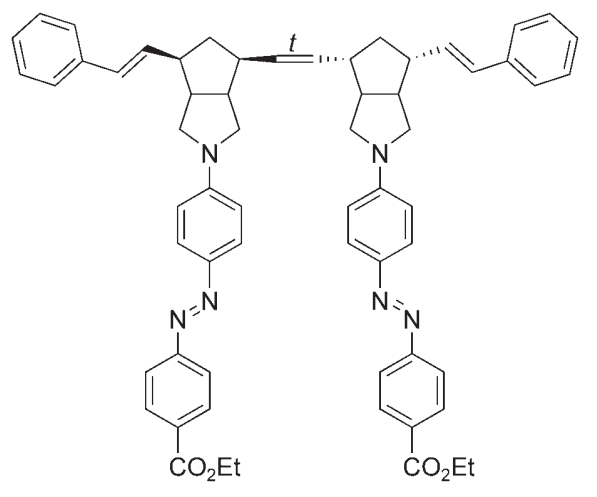

$11 \mathrm{~b}$
Scheme 3. Synthesis of dimers 11. a) Styrene, $1, \mathrm{CH}_{2} \mathrm{Cl}_{2}, 24 \mathrm{~h}, 75 \%$; b) $\mathrm{LiAlH}_{4}$, diethyl ether/ $\mathrm{CH}_{2} \mathrm{Cl}_{2}(2: 1)$ $84 \%$; c) ethyl 4-aminobenzoate, $\mathrm{HNO}_{2}, 93 \%$; d) $\mathbf{1 6}, \mathrm{CH}_{2} \mathrm{Cl}_{2}, 24 \mathrm{~h}, 71 \%$. $t=$ trans double bond.

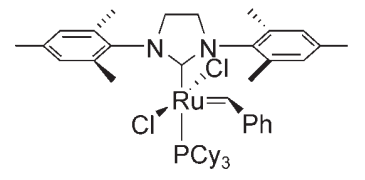

16

Table 1. Absorption maxima and EFISH ${ }^{[a]}$ data of 11a, 11b, and 12.

\begin{tabular}{lllll}
\hline Compound & $\begin{array}{l}\lambda_{\max }[\mathrm{nm}] \\
\left(\varepsilon\left[\mathrm{g}^{-1} \mathrm{~cm}^{2}\right]\right)\end{array}$ & $\begin{array}{l}\mu \beta^{[\mathrm{a}]} \\
{\left[10^{-46} \mathrm{esu}\right]}\end{array}$ & $\begin{array}{l}\mu \beta_{0}{ }^{\mathrm{b}]} \\
{\left[10^{-46} \mathrm{esu}\right]}\end{array}$ & $\begin{array}{l}\mu \beta_{0}(\mathbf{1 1}) / \mu \beta_{0} \\
\mathbf{( 1 2})\end{array}$ \\
\hline $\mathbf{1 2}$ & $441(28.0)$ & 3.8 & 2.7 & 1 \\
$\mathbf{1 1 a}$ & $440(27.4)$ & 6.1 & 4.3 & 1.6 \\
$\mathbf{1 1 b}$ & $400(27.5)$ & 5.3 & 3.8 & 1.4
\end{tabular}

[a] All $\mu \beta$ values were measured in chloroform at $1907 \mathrm{~nm}$. [b] $\mu \beta_{0}$ values were deduced from the experimental values by using a two-level dispersion model. ${ }^{[13,14]}$

11b have a trans configuration. The large ${ }^{1} \mathrm{H}$ NMR coupling constant $(J=15.1 \mathrm{~Hz})$ for the two olefinic protons of $\mathbf{1 1 a}$ further supports this argument. The ${ }^{13} \mathrm{C}$ NMR spectrum for 11a has seven pairs of signals at high field, whereas that for 11b has only seven peaks. These results suggest that 11a has $C_{1}$ symmetry and, therefore, is isotactic. On the other hand, 11b has $C_{2}$ symmetry and, hence, is syndiotactic. ${ }^{[15]}$ These results provide a useful hint for the elucidation of the tacticity of the polymers as described later.

X-ray analysis of $\mathbf{1 4}$ suggested that the distance between the two olefinic moieties is 5$6 \AA{ }^{[3 b]}$ and STM of 2 showed that the $\mathrm{Fe}-\mathrm{Fe}$ distance is 5$5.5 \AA^{[1]}$ It is therefore envisaged that each of the monomeric units in $\mathbf{2}$ and its related polymers may also occupy a similar amount of space. Rotation along the carbon-nitrogen bond in $\mathbf{1 1}$ may bring two neighboring arene moieties closer so that interaction between these chromophores might take place.

\section{Polymer 6}

We previously showed that 6 may adopt homogeneous tacticity based on its spectroscopic data and nonlinear optical properties. ${ }^{[3]}$ As described above, the stereochemistry of dimers 11 were established with the help of ${ }^{13} \mathrm{CNMR}$ spectroscopy. Interestingly, two peaks of equal intensity at 35.46 and 35.95 ppm attributed to $\mathrm{C}^{[2]}$ were observed in the ${ }^{13} \mathrm{CNMR}$ spectrum of $\mathbf{6}$ (Figure 1). This observation suggests that there are two types of nonequivalent $\mathrm{C} 7$ atoms in $\mathbf{6}$.

As described previously, polynorbornenes obtained by ROMP with the Grubbs I catalyst have double bonds in trans configurations. ${ }^{[3,9]}$ The dipolar pendant groups are coherently aligned in the syn configuration. ${ }^{[3]}$ Scheme 4 shows the possible structures of the isotactic and syndiotactic polymers 6. For syn conformations, the syndiotactic structure has a $C_{2}$ symmetry axis bisecting the carbon-carbon double bond. As such, the environments for each of the neighboring monomeric units are the same, and only one set of ${ }^{13} \mathrm{C}$ NMR signals would be expected. In the isotactic structure, on the other hand, there is a plane of symmetry perpendicular to the polymeric backbone and bisecting each monomeric unit. However, the two planes of symmetry ( $\sigma$ and $\sigma^{\prime}$ ) in two neighboring units are different; therefore, two sets of ${ }^{13} \mathrm{C}$ NMR signals would be anticipated. For anti conformations, the isotactic structure has the center of inversion $(i)$ at 


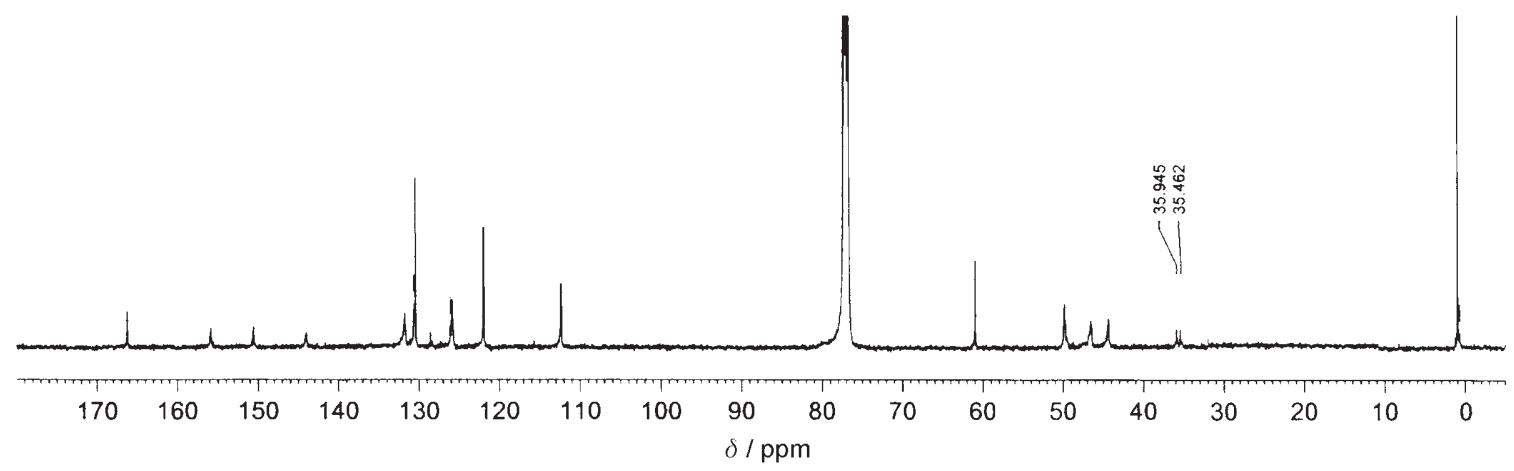

Figure $1 .{ }^{13} \mathrm{C}$ NMR spectrum of polymer 6 .

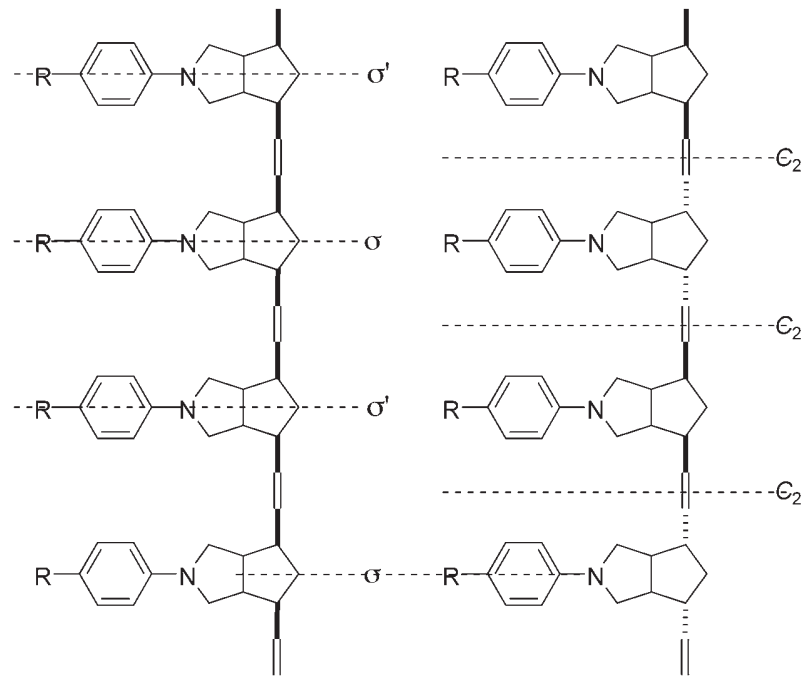

Isotactic syn

Syndiotactic syn

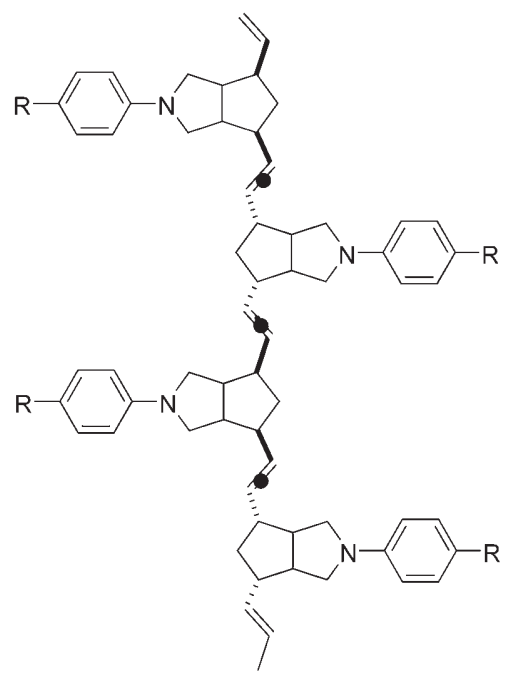

Isotactic anti

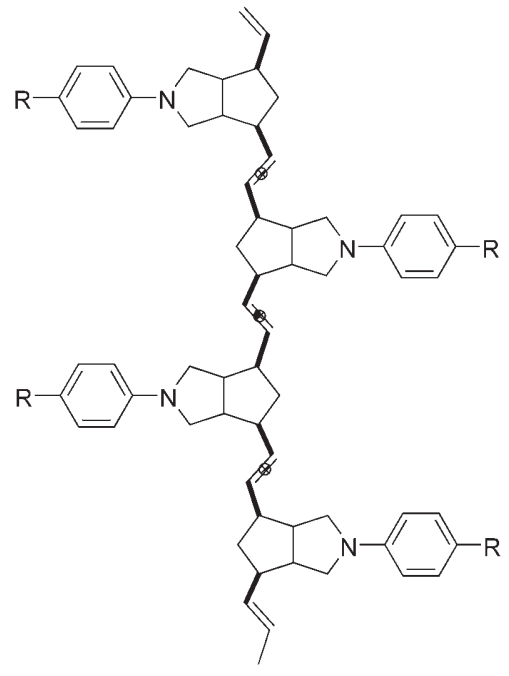

Syndiotactic anti

Scheme 4. Possible conformations of isotactic and syndiotactic polymers 6.

the center of the carbon-carbon double bond, whereas the syndiotactic form has the $C_{2}$ rotation axis perpendicular to the polymeric backbone and orthogonal to the correspond- ing $C_{2}$ axis of the syn conformation. One might expect that both structures with anti conformation would show only one set of ${ }^{13} \mathrm{C}$ NMR signals.

On the basis of this analysis, it seems likely that polymer 6 adopts isotactic stereochemistry. It is believed that interactions between pendant chromophores may play an important role in dictating the stereochemistry of the polynorbornenes. Interaction between these chromophores may depend on the relative electron demand of the aromatic rings. The substituents on these aryl pendant groups may influence the mode of such interactions, which may result in changes in the stereochemistry of the polymer. Accordingly, a series of polymers 17 with different substituents at the para position of the pendant phenyl groups were synthesized (Scheme 5). Different numberaverage molecular weights $\left(M_{\mathrm{n}}\right)$ for 17 were obtained. ${ }^{[4,5]}$ Table 2 summarizes the selected photophysical properties of these polymers.

\section{Absorption Properties of 17}

As is the case with the polynorbornenes 6 with azo pendant groups, ${ }^{[3]}$ the $\lambda_{\max }$ values of 17 also consistently appeared at shorter wavelengths relative to those of the corresponding monomers $\mathbf{1 8}$, and the UV/Vis absorption profiles remained unchanged with changes in concentration. In gen- 

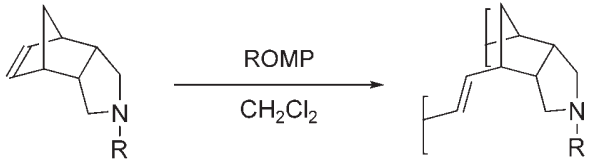

17

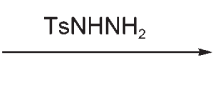

b<smiles>[R]=[Fe]C(C)(C)c1ccc(C(F)(F)F)cc1</smiles><smiles>CCOc1ccc(C(C)(C)C)cc1</smiles><smiles>Cc1ccc(Br)cc1</smiles><smiles>Cc1ccc(I)cc1</smiles>

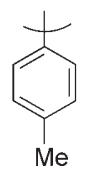

Scheme 5. Synthesis of saturated polymer 19. Ts $=$ tosyl.

Table 2. Absorption data of monomers $18 \mathbf{a}-\mathbf{f}$ and polymers $17 \mathbf{a}-\mathbf{f}$ of different molecular weights.

\begin{tabular}{|c|c|c|c|c|c|c|}
\hline Compound $^{[\mathrm{a}]}$ & $M_{\mathrm{n}}$ & $\mathrm{PDI}^{[\mathrm{b}]}$ & $n$ & $\begin{array}{l}\lambda_{\max } \\
{[\mathrm{nm}]}\end{array}$ & $\begin{array}{l}\varepsilon \\
{\left[\mathrm{g}^{-1} \mathrm{~cm}^{2}\right]}\end{array}$ & $\varepsilon_{\mathrm{d}}$ \\
\hline $18 \mathbf{a}$ & 279 & & 1 & 273 & 83.1 & \\
\hline $17 \mathbf{a}-1$ & 6999 & 1.17 & 25 & 270 & 43.5 & 47.6 \\
\hline $17 \mathbf{a}-2$ & 10901 & 1.18 & 39 & 270 & 27.7 & 66.7 \\
\hline $17 \mathbf{a}-3$ & 18114 & 1.31 & 65 & 270 & 16.0 & 80.7 \\
\hline $18 b$ & 283 & & 1 & 317 & 122.5 & \\
\hline $17 b-1$ & 9888 & 1.20 & 35 & 313 & 103.7 & 15.3 \\
\hline $17 b-2$ & 15658 & 1.32 & 55 & 313 & 98.8 & 19.3 \\
\hline $17 b-3$ & 28152 & 1.49 & 99 & 313 & 98.4 & 19.6 \\
\hline $18 \mathrm{c}$ & 289 & & 1 & 268 & 64.3 & \\
\hline $17 c-1$ & 5531 & 1.13 & 19 & 265 & 41.8 & 35.0 \\
\hline $17 c-2$ & 9593 & 1.35 & 25 & 265 & 36.1 & 43.8 \\
\hline $17 c-3$ & 21421 & 1.05 & 74 & 265 & 32.6 & 49.3 \\
\hline $18 d$ & 211 & & 1 & 260 & 75.1 & \\
\hline $17 d-1$ & 7669 & 1.13 & 36 & 256 & 61.1 & 18.6 \\
\hline $17 d-2$ & 9958 & 1.25 & 47 & 256 & 57.3 & 23.6 \\
\hline $17 d-3$ & 12485 & 1.17 & 59 & 256 & 55.9 & 25.5 \\
\hline $18 \mathrm{e}$ & 225 & & 1 & 257 & 63.8 & \\
\hline $17 \mathrm{e}-1$ & 5249 & 1.11 & 23 & 255 & 56.6 & 11.2 \\
\hline $17 \mathrm{e}-2$ & 7236 & 1.15 & 32 & 255 & 55.6 & 12.9 \\
\hline $17 \mathrm{e}-3$ & 12985 & 1.06 & 58 & 255 & 55.5 & 13.0 \\
\hline $18 \mathrm{f}$ & 241 & & 1 & 253 & 61.4 & \\
\hline $17 \mathrm{f}-1$ & 10041 & 1.52 & 42 & 251 & 55.7 & 9.2 \\
\hline $17 \mathrm{f}-2$ & 13048 & 1.42 & 54 & 251 & 54.9 & 10.7 \\
\hline $17 \mathrm{f}-\mathbf{3}$ & 16253 & 1.33 & 67 & 251 & 54.3 & 11.5 \\
\hline
\end{tabular}

[a] Numbers after the dashes denote polymers of different $M_{\mathrm{n}}$. [b] PDI= polydispersity index $\left(M_{\mathrm{w}} / M_{\mathrm{n}}\right)$.

eral, with the exception of $\mathbf{1 7 b}$ and $\mathbf{1 8 b}$, monomers 18 and polymers $\mathbf{1 7}$ exhibited both $E$ and $B$ bands at $250-270$ and $310-330 \mathrm{~nm}$, respectively. These two bands, however, merged into one for $\mathbf{1 7 b}$ and $\mathbf{1 8 b}$ at around $313 \mathrm{~nm}$. In all cases, the extinction coefficients $\left(\mathrm{g}^{-1} \mathrm{~cm}^{2}\right)$ of $\mathbf{1 7}$ decreased with an increase in the degree of polymerization. The percentage decrease in the relative extinction coefficient of the polymer, $\varepsilon_{\mathrm{d}}$, is defined in [Eq. (1)]:

$\varepsilon_{\mathrm{d}}=\left[1-\left(\varepsilon_{\mathrm{p}} / \varepsilon_{\mathrm{m}}\right)\right] \times 100$

in which $\varepsilon_{\mathrm{p}}$ and $\varepsilon_{\mathrm{m}}$ are the extinction coefficients $\left(\mathrm{g}^{-1} \mathrm{~cm}^{2}\right)$ for $\mathbf{1 7}$ and the corresponding monomer $\mathbf{1 8}$, respectively. The $\varepsilon_{\mathrm{d}}$ values at $250-270 \mathrm{~nm}$ for 17 a-f were thus obtained, and the results are summarized in Table 2. ${ }^{[16]}$ A plot of these $\varepsilon_{\mathrm{d}}$ values of $\mathbf{1 7}$ for a given substituent against the average number of repeating units, $n$ $(15<n<99)$, is shown in Figure 2. ${ }^{[16]}$ Interestingly, the $\varepsilon_{\mathrm{d}}$ values are larger for polymers with electron-withdrawing substituents and smaller for those with electron-donating substituents. From these plots, a

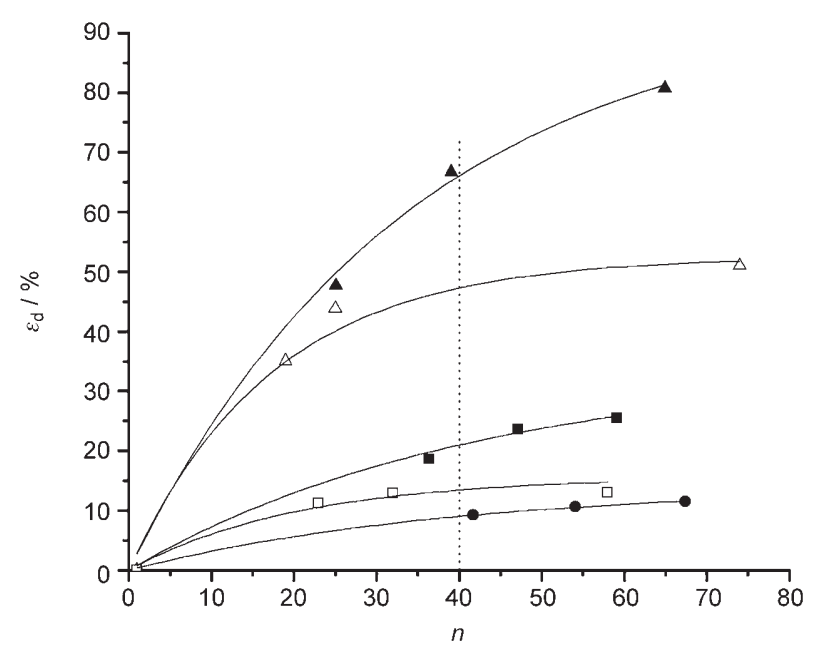

Figure 2. Plots of the $\varepsilon_{\mathrm{d}}$ values of $\mathbf{1 7}$ against the average number of repeating units $n$. Substituents: $\boldsymbol{\Delta}=\mathrm{CF}_{3}, \triangle=\mathrm{Br}, \boldsymbol{\square}=\mathrm{H}, \square=\mathrm{Me}$, OMe.

series of $\varepsilon_{\mathrm{d}}{ }^{40}$ values for $\mathbf{1 7} \mathbf{a}-\mathbf{f}$ with 40 repeating units were estimated by intra- or extrapolations (Figure 2, dotted line). As shown in Figure 3, the Hammett plot ${ }^{[17]}$ of these $\varepsilon_{\mathrm{d}}{ }^{40}$ values gave a good linear relationship $\left(R^{2}=0.992\right)$. These results indicate that interchromophore interactions among the pendant groups of $\mathbf{1 7}$ are more important for those with electron-withdrawing rather than electron-donating substituents.

The pyrrolidine moiety in $\mathbf{1 7}$ is a strongly electron donating group. When the other substituent on the aromatic ring in $\mathbf{1 7}$ is also an electron-donating group, the aromatic rings would be highly electron-rich. As such, the modes of interaction between such electron-rich chromophores may be different from those with electron-withdrawing substituents. Such differences may lead to discrepancies in the $\varepsilon_{\mathrm{d}}$ values due to the nature of the substituents.

It is known that substituents on phenylene ethynylene macrocycles and related cyclic conjugated systems may have 


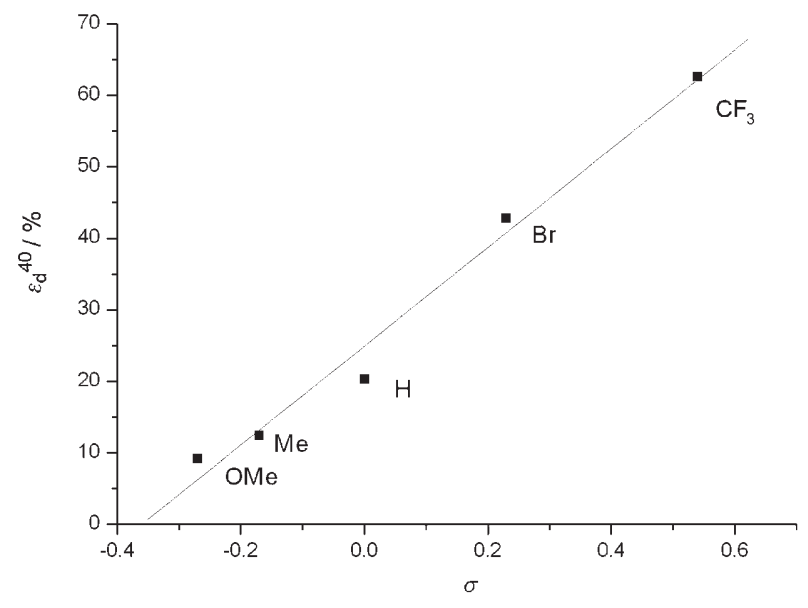

Figure 3. Hammett plot of the $\varepsilon_{\mathrm{d}}{ }^{40}$ values of $\mathbf{1 7}$.

a direct influence on $\pi$-stacking tendency. ${ }^{[18,19]}$ In general, electron-withdrawing groups such as the ester function may favor $\pi$-stacking interactions, whereas such aggregation may become less favorable in those substrates with electron-donating substituents such as alkoxy groups. ${ }^{[19]}$ Although the quantitative relationship remains to be clarified, our results on polynorbornenes may be compatible with those in the literature $^{[18,19]}$ in which interactions between the chromophores may be substituent-dependent. For electron-withdrawing substituents, such interactions may be more important. Therefore, the pendant chromophores in these polymers (e.g., 17a-c) may align coherently in similar directions. Powder X-ray analysis of $\mathbf{1 7} \mathbf{b}$ suggested that the polymer is amorphous, with a broad peak at $2 \theta=18.76^{\circ}$.

\section{Effect of Substituent on the ${ }^{13} \mathrm{C}$ NMR Spectrum of 17}

Figure 4 shows the ${ }^{13} \mathrm{C}$ NMR spectra of $\mathbf{1 7 b}$ and the corresponding hydrogenated polymer $\mathbf{1 9 b}$. The simplicity of the spectrum for 19b suggests that this polymer may adopt a single tacticity. ${ }^{[10,11]}$ As with the spectrum of $\mathbf{6}$, the high-field signals assigned to $\mathrm{C}^{[2]}$ for $\mathbf{1 7} \mathbf{b}$ occur as two peaks of equal

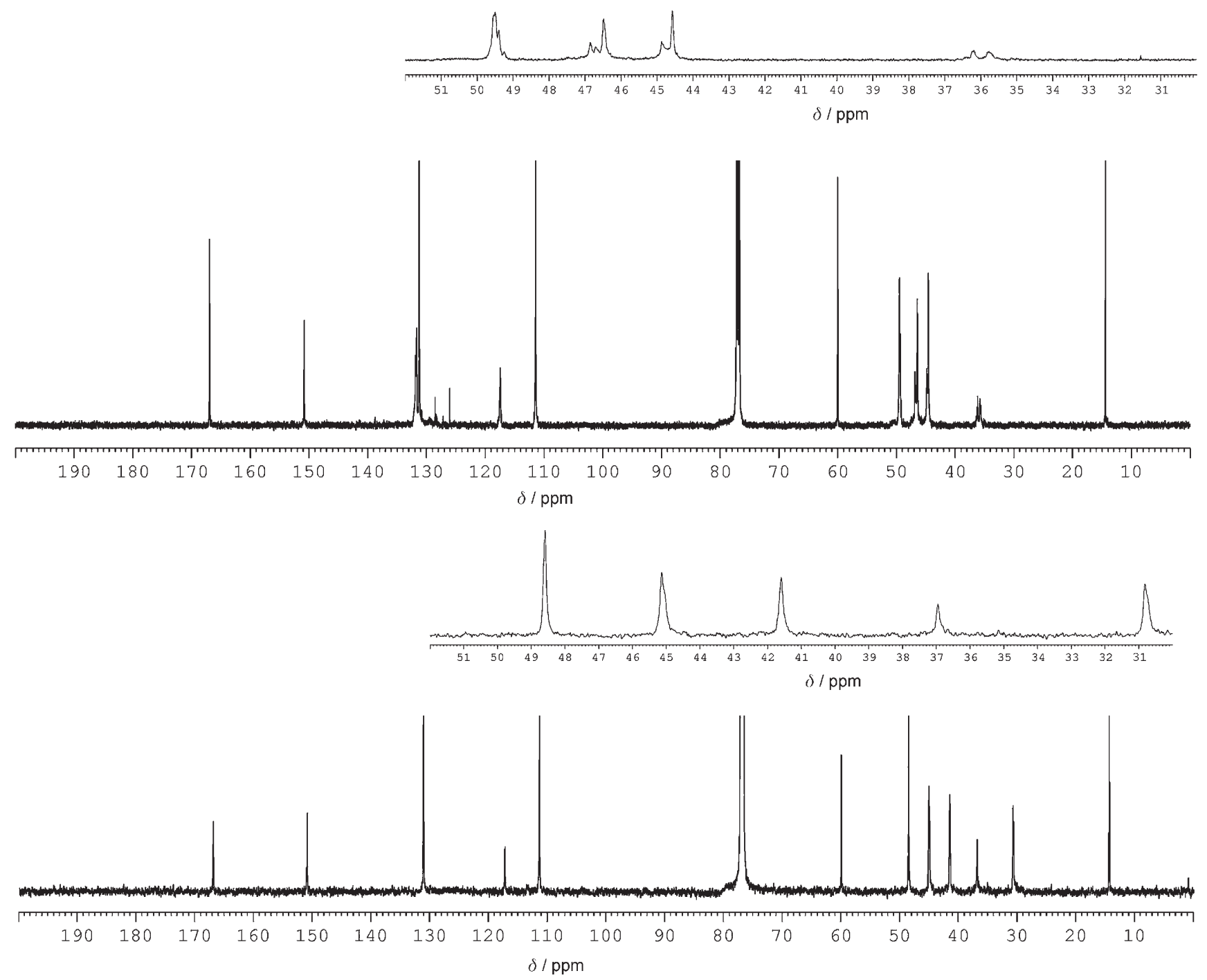

Figure 4. ${ }^{13} \mathrm{C}$ NMR spectra of a) $\mathbf{1 7} \mathbf{b}$ and b) 19b. Insets: Corresponding expanded high-field region. 
intensity at 35.75 and $36.21 \mathrm{ppm}$. These signals are independent of the degree of polymerization. In a similar manner, the signals for this carbon atom of $\mathbf{1 7} \mathbf{a}$ (35.63 and $36.12 \mathrm{ppm}$ ) and $17 \mathrm{c}(35.56$ and $35.80 \mathrm{ppm})$ also show two peaks at high field. Interestingly, the separation of these two peaks $(\Delta \delta)$ is substituent-dependent. The more strongly electron withdrawing group gave a larger $\Delta \delta$ value. On the other hand, the ${ }^{13} \mathrm{C}$ NMR signals of $\mathrm{C} 7$ for $\mathbf{1 7} \mathbf{d}-\mathbf{f}$ with electron-donating substituents or hydrogen appeared as a single peak $(\Delta \delta=0 \mathrm{ppm})$.

The change in $\Delta \delta$ with substituents is interesting. For polymers $\mathbf{1 7} \mathbf{a}-\mathbf{c}$ with electron-withdrawing substituents, $\pi$ stacking interactions between neighboring aromatic chromophores may be significant. Accordingly, on the basis of the structures shown in Scheme 4, it seems likely that these polymers may adopt the isotactic structure with syn conformation. As the substituents become more electron-donating, such $\pi$-stacking tendencies would become less important. Interactions between two neighboring aromatic rings in such polymers (those with electron-donating substituents) may, therefore, be unfavorable. These tendencies may lead to conformational changes or even perturbation of the stereoregularities in polynorbornenes.

\section{Polymers from exo-Norbornene Derivatives}

Polymers 20 and 21, derived from the corresponding exo isomer $22 \mathbf{a}$ and the corresponding furan adduct $\mathbf{2 3} \mathbf{a}$, respec-
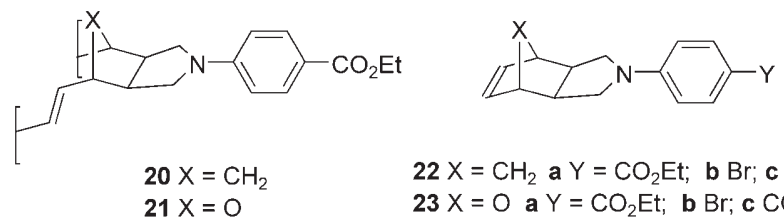

$20 X=\mathrm{CH}_{2}$
$21 \mathrm{X}=\mathrm{O}$

$22 \mathrm{X}=\mathrm{CH}_{2}$ a $\mathrm{Y}=\mathrm{CO}_{2} \mathrm{Et} ; \boldsymbol{b} \mathrm{Br} ; \mathrm{c} \mathrm{CO}_{2} \mathrm{H}$ $23 X=\mathrm{O}$ a $\mathrm{Y}=\mathrm{CO}_{2} \mathrm{Et} ; \mathbf{b} \mathrm{Br} ; \mathbf{c ~} \mathrm{CO}_{2} \mathrm{H}$

tively, were prepared for comparison. Interestingly, both $\mathbf{2 0}$ and 21 may contain both cis and trans double bonds. Furthermore, the extinction coefficients of $\mathbf{2 0}$ and $\mathbf{2 1}$ are essentially the same as those of $22 \mathbf{a}$ and $23 \mathbf{a}$, respectively. These results indicate that the stereoselectivity for polymerization of the exo derivatives of norbornene and related skeletons may not be as good as those of the corresponding endo isomers.

\section{Conclusions}

A series of polynorbornenes with aryl substituents on the 5,6-endo pendant groups has been synthesized by Grubbs I catalyst mediated ROMP of the corresponding norbornene monomers. The tacticity of these polymers and the related dimers has been examined by UV/Vis and ${ }^{13} \mathrm{C}$ NMR spectroscopy, and their nonlinear optical properties have been probed. The results suggest that polynorbornenes that contain aryl groups with electron-withdrawing substituents may adopt isotactic stereochemistry with all the pendant groups aligned in one direction. Interaction between these chromophores may take place in these polymers. Such interaction may also be important in directing the stereochemistry of the polymer during the course of the ROMP process of norbornenes with aryl pendant groups. More importantly, the present work echoes our previous successful synthesis of double-stranded polymers ${ }^{[1]}$ because of the nice coherent alignment of the pendant groups and the homogeneous tacticity in the polymerization of norbornene derivatives. The corresponding polymers derived from the exo isomers appeared less stereoregular.

\section{Experimental Section}

\section{General}

Gel permeation chromatography (GPC) was performed on a Waters GPC machine with an isocratic HPLC pump (1515) and a refractiveindex detector (2414). THF was used as the eluent (flow rate= $\left.1.0 \mathrm{mLmin}^{-1}\right)$. Waters Styragel HR2, HR3, and HR4 columns $(7.8 \times$ $300 \mathrm{~mm}$ ) were employed for determination of relative molecular weight with polystyrene as standard $\left(M_{\mathrm{n}}\right.$ values ranged from 375 to $\left.3.5 \times 10^{6}\right)$.

\section{EFISH Measurements}

EFISH measurements were taken with a nonlinear optical spectrometer from SOPRA. The fundamental wavelength at $1907 \mathrm{~nm}$ is the first Stokes peak of a hydrogen Raman cell pumped by the 1064-nm light from a Qswitched Nd/YAG laser (Quantel YG 781, $10 \mathrm{pps}, 8 \mathrm{~ns}$, pulse). That light was passed through a linear polarizer and focused onto the EFISH cell. The polarizing dc voltage (parallel to the light polarization) used in this cell was $10 \mathrm{kV}$. The output light from the cell was passed through an interference filter to select the second harmonic $(954 \mathrm{~nm})$, which was detected with an R642 photomultiplier from Hamamatsu. Static $\mu \beta_{0}$ values were deduced from the experimental values by using a two-level dispersion model. Each sample was measured with chloroform $\left(\mathrm{CHCl}_{3}\right)$ as solvent, and the concentration was about $10^{-3} \mathrm{M}$ for monomers.

\section{Syntheses}

15: Compound $14(1.03 \mathrm{~g}, 3.0 \mathrm{mmol})$ in $\mathrm{CH}_{2} \mathrm{Cl}_{2}(50 \mathrm{~mL})$ was added slowly to a slurry of $\mathrm{LiAlH}_{4}(0.68 \mathrm{~g}, 18 \mathrm{mmol})$ in $\mathrm{Et}_{2} \mathrm{O}(100 \mathrm{~mL})$, and the mixture was stirred at room temperature for $1 \mathrm{~h}$. Ethyl acetate $(5 \mathrm{~mL})$ was carefully added, water $(1 \mathrm{~mL})$ was then introduced, the resulting suspension was filtered, and the organic layer was evaporated in vacuo to give the residue, which was triturated repeatedly with $\mathrm{CH}_{2} \mathrm{Cl}_{2}$. The solution in $\mathrm{CH}_{2} \mathrm{Cl}_{2}$ was dried $\left(\mathrm{MgSO}_{4}\right)$ and filtered. The solvent was removed in vacuo to give 15 as a colorless liquid $(0.79 \mathrm{~g}, 84 \%)$. IR $(\mathrm{KBr}): \tilde{v}=3023$, 2958, 2912, 2848, 1774, 1706, 1594, 1491, 1455, 1384, 1322, 1291, 1192, 1167, 107, 961, 921, 873,815, 772, 755, 694, 622, $586 \mathrm{~cm}^{-1} ;{ }^{1} \mathrm{H}$ NMR $\left(400 \mathrm{MHz}, \mathrm{CDCl}_{3}\right): \delta=1.70(\mathrm{q}, J=12.0 \mathrm{~Hz}, 1 \mathrm{H}), 1.96(\mathrm{dt}, J=12.0,5.9 \mathrm{~Hz}$, $1 \mathrm{H}), 2.83-3.10(\mathrm{~m}, 4 \mathrm{H}), 3.26(\mathrm{brt}, J=6.9 \mathrm{~Hz}, 4 \mathrm{H}), 5.11(\mathrm{~d}, J=10.3 \mathrm{~Hz}$, $1 \mathrm{H}), 5.15(\mathrm{~d}, J=17.2 \mathrm{~Hz}, 1 \mathrm{H}), 5.93(\mathrm{ddd}, J=17.2,10.3,3.5 \mathrm{~Hz}, 1 \mathrm{H}), 6.30$ $(\mathrm{dd}, J=16.0,7.2 \mathrm{~Hz}, 1 \mathrm{H}), 6.46(\mathrm{~d}, J=16.0 \mathrm{~Hz}, 1 \mathrm{H}), 6.69(\mathrm{~d}, J=8.2 \mathrm{~Hz}$, $1 \mathrm{H}), \quad 6.76(\mathrm{t}, \quad J=8.8 \mathrm{~Hz}, \quad 1 \mathrm{H}), \quad 7.23-7.36 \mathrm{ppm} \quad(\mathrm{m}, \quad 8 \mathrm{H}) ;{ }^{13} \mathrm{C}$ NMR $\left(100 \mathrm{MHz}, \mathrm{CDCl}_{3}\right): \delta=35.3,45.5,46.1,46.2,46.7,50.3,50.4,113.4,115.3$, $116.8,126.1,127.1,128.5,129.1,130.5,131.1,137.5,139.1,148.6 \mathrm{ppm}$; HRMS (FAB): $m / z$ calcd for $\mathrm{C}_{23} \mathrm{H}_{25} \mathrm{~N}: 315.1987[M]^{+}$; found: 315.1989 ; elemental analysis: calcd (\%) for $\mathrm{C}_{23} \mathrm{H}_{25} \mathrm{~N}$ : C 87.57, H 7.99, N 4.44; found: C 87.99, H 7.64, N 4.20.

12: A solution of $\mathrm{NaNO}_{2}(76 \mathrm{mg}, 1.1 \mathrm{mmol})$ in a minimum amount of water was added to a mixture of ethyl 4-aminobenzoate $(165 \mathrm{mg}$, $1.0 \mathrm{mmol})$ and $\mathrm{HCl}(5 \mathrm{~mL}, 50 \%)$ cooled to $5^{\circ} \mathrm{C}$. After $3 \mathrm{~min}, \mathbf{1 5}(315 \mathrm{mg}$, $1.0 \mathrm{mmol})$ in THF $(5 \mathrm{~mL})$ was added slowly, and stirring continued for $2 \mathrm{~h}$. The reaction mixture was warmed to room temperature, neutralized with $\mathrm{NaOAc}$, and stirred at room temperature overnight. $\mathrm{CH}_{2} \mathrm{Cl}_{2}$ 
$(50 \mathrm{~mL})$ was added, and the organic layer was washed with $\mathrm{NaHCO}_{3}$ $(5 \%, 3 \times 100 \mathrm{~mL})$ and brine $(100 \mathrm{~mL})$ and then dried $\left(\mathrm{MgSO}_{4}\right)$. Removal of the solvent in vacuo and purification on silica gel $\left(\mathrm{CH}_{2} \mathrm{Cl}_{2} /\right.$ hexane $=$ 1:1) afforded 12 as a red solid (456 mg, 93\%). M.p.: 191-192 ${ }^{\circ} \mathrm{C}$; IR $(\mathrm{KBr}): \tilde{v}=3076,2976,2951,2935,2859,1713,1598,1513,1478,1421$, 1366, 1273, 1170, 1135, 1107, 1012, 963, $910 \mathrm{~cm}^{-1} ;{ }^{1} \mathrm{H}$ NMR $(400 \mathrm{MHz}$, $\left.\mathrm{CDCl}_{3}\right): \delta=1.40(\mathrm{t}, J=7.0 \mathrm{~Hz}, 3 \mathrm{H}), 1.65(\mathrm{q}, J=12.0 \mathrm{~Hz}, 1 \mathrm{H}), 1.99$ (dt, $J=12.0,5.9 \mathrm{~Hz}, 1 \mathrm{H}), 2.83-3.10(\mathrm{~m}, 4 \mathrm{H}), 3.30-3.40(\mathrm{~m}, 4 \mathrm{H}), 4.37(\mathrm{q}, J=$ $7.0 \mathrm{~Hz}, 2 \mathrm{H}), 5.07-5.11(\mathrm{~m}, 2 \mathrm{H}), 5.93(\mathrm{ddd}, J=17.2,10.3,3.5 \mathrm{~Hz}, 1 \mathrm{H})$, $6.16(\mathrm{dd}, J=16.0,7.2 \mathrm{~Hz}, 1 \mathrm{H}), 6.43(\mathrm{~d}, J=16.0 \mathrm{~Hz}, 1 \mathrm{H}), 6.65(\mathrm{~d}, J=$ $9.0 \mathrm{~Hz}, 2 \mathrm{H}), 7.19-7.32(\mathrm{~m}, 5 \mathrm{H}), 8.16 \mathrm{ppm}(\mathrm{d}, J=9.0 \mathrm{~Hz}, 2 \mathrm{H}) ;{ }^{13} \mathrm{C} \mathrm{NMR}$ $\left(100 \mathrm{MHz}, \mathrm{CDCl}_{3}\right): \delta=14.4,35.3,45.2,45.9,46.3,46.8,49.8,50.0,61.0$, $112.5,115.8,121.9,125.7,126.1,127.3,128.6,130.4,130.5,130.6,131.0$, 137.3, 138.8, 143.9, 150.6, 155.9, 166.4 ppm; HRMS (FAB): $m / z$ calcd for $\mathrm{C}_{32} \mathrm{H}_{34} \mathrm{~N}_{3} \mathrm{O}_{2}$ : $492.2651[M+\mathrm{H}]^{+}$; found: 492.2650; elemental analysis: calcd (\%) for $\mathrm{C}_{32} \mathrm{H}_{33} \mathrm{~N}_{3} \mathrm{O}_{2}$ : C 78.18, $\mathrm{H} \mathrm{6.77,} \mathrm{N} \mathrm{8.55;} \mathrm{found:} \mathrm{C} 77.95, \mathrm{H}$ 6.70, N 8.65

11: Under argon, a solution of $\mathbf{1 2}(984 \mathrm{mg}, 2 \mathrm{mmol})$ and $\mathbf{1 6}(169 \mathrm{mg}$, $0.2 \mathrm{mmol})$ in $\mathrm{CH}_{2} \mathrm{Cl}_{2}(4 \mathrm{~mL})$ was heated under reflux for $24 \mathrm{~h}$, cooled to room temperature, and the reaction was quenched with ethyl vinyl ether $(1 \mathrm{~mL})$. Removal of the solvent in vacuo followed by chromatographic purification (silica gel, EtOAc/hexane $=1: 1)$ afforded 11a $(438 \mathrm{mg}, 46 \%)$ and $11 \mathbf{b}(239 \mathrm{mg}, 25 \%)$. 11a: M.p.: $210-211^{\circ} \mathrm{C}$; IR (KBr): $\tilde{v}=2949,2831$, 1711, 1597, 1523,1384, 1282, 1135, 1131, 1111, 959, 857, $816 \mathrm{~cm}^{-1}$; ${ }^{1} \mathrm{H}$ NMR $\left(500 \mathrm{MHz}, \mathrm{CDCl}_{3}\right): \delta=1.47(\mathrm{t}, J=7.0 \mathrm{~Hz}, 6 \mathrm{H}), 1.67-2.00(\mathrm{~m}$, $4 \mathrm{H}), 2.95-3.10(\mathrm{~m}, 8 \mathrm{H}), 3.30-3.40(\mathrm{~m}, 8 \mathrm{H}), 4.43(\mathrm{q}, J=7.0 \mathrm{~Hz}, 4 \mathrm{H}), 5.48$ $(\mathrm{d}, J=15.1 \mathrm{~Hz}, 2 \mathrm{H}), 6.19(\mathrm{dd}, J=6.6,15.8 \mathrm{~Hz}, 1 \mathrm{H}), 6.21(\mathrm{dd}, J=7.5$, $15.8 \mathrm{~Hz}, 1 \mathrm{H}), 6.43(\mathrm{~d}, J=15.8,1 \mathrm{H}), 6.45(\mathrm{~d}, J=15.8 \mathrm{~Hz}, 1 \mathrm{H}), 6.61(\mathrm{~d}, J=$ $8.4 \mathrm{~Hz}, 2 \mathrm{H}), 6.65(\mathrm{~d}, J=8.4 \mathrm{~Hz}, 2 \mathrm{H}), 7.22-7.40(\mathrm{~m}, 10 \mathrm{H}), 7.79-8.01(\mathrm{~m}$, $8 \mathrm{H}), 8.10 \mathrm{ppm}(\mathrm{d}, J=8.4 \mathrm{~Hz}, 4 \mathrm{H}) ;{ }^{13} \mathrm{C}$ NMR $\left(125 \mathrm{MHz}, \mathrm{CDCl}_{3}\right): \delta=14.1$, 35.4, 35.5, 44.3, 44.5, 44.9, 45.0, 46.1, 46.3, 46.6, 46.7, 48.7, 49.9, 61.1, $121.5,126.0,127.3,128.3,128.5,128.7,130.1,130.4,130.8,131.7,137.0$, 143.6, 150.9, $166.1 \mathrm{ppm}$; HRMS $(\mathrm{FAB}+): \mathrm{m} / z$ calcd for $\mathrm{C}_{62} \mathrm{H}_{62} \mathrm{~N}_{6} \mathrm{O}_{4}$ : 954.4833 $[M]^{+}$; found: 954.4839; elemental analysis: calcd $(\%)$ for $\mathrm{C}_{62} \mathrm{H}_{62} \mathrm{~N}_{6} \mathrm{O}_{4}$ : C 77.96, H 6.54, N 8.80; found: C 78.15, H 6.77, N 8.64. 11b: M.p.: $211-213^{\circ} \mathrm{C}$; IR (KBr): $\tilde{v}=2950,2822,1711,1597,1539,1522,1384$, 1255, 1145, 1131, 1111, 960, 859, $820 \mathrm{~cm}^{-1} ;{ }^{1} \mathrm{H}$ NMR $\left(500 \mathrm{MHz}, \mathrm{CDCl}_{3}\right)$ : $\delta=1.47(\mathrm{t}, J=7.0 \mathrm{~Hz}, 6 \mathrm{H}), 1.67-1.68(\mathrm{~m}, 2 \mathrm{H}), 1.90-2.00(\mathrm{~m}, 2 \mathrm{H}), 2.90$ $3.43(\mathrm{~m}, 16 \mathrm{H}), 4.42(\mathrm{q}, J=7.0 \mathrm{~Hz}, 4 \mathrm{H}), 5.45(\mathrm{~s}, 2 \mathrm{H}), 6.15-6.17(\mathrm{~m}, 2 \mathrm{H})$, 6.40-6.52 (m, 2H), 6.71-6.80 (m, 4H), 7.22-7.49 (m, 10H), 7.79-8.01 (m, $8 \mathrm{H}), 8.10 \mathrm{ppm}(\mathrm{d}, J=8.3 \mathrm{~Hz}, 4 \mathrm{H}) ;{ }^{13} \mathrm{C}$ NMR $\left(125 \mathrm{MHz}, \mathrm{CDCl}_{3}\right): \delta=14.1$, $35.8,44.5,45.0,46.4,46.9,49.8,49.9,60.8,112.7,121.5,126.0,126.3,127.1$, 128.1, 128.4, 130.2, 130.5, 131.1, 131.7, 137.2, 143.5, 150.9, $166.0 \mathrm{ppm}$; HRMS $(\mathrm{FAB}+): m / z$ calcd for $\mathrm{C}_{62} \mathrm{H}_{62} \mathrm{~N}_{6} \mathrm{O}_{4}: 954.4833[M]^{+}$; found: 954.4832 .

18a: 4-(4-Trifluoromethylphenyl)-4-azatricyclo[5.2.1.0 $\left.0^{2,6}\right]$ dec-8-en-3,5dione ${ }^{[20]}(3.1 \mathrm{~g}, 10.0 \mathrm{mmol})$ in $\mathrm{CH}_{2} \mathrm{Cl}_{2}(50 \mathrm{~mL})$ was added slowly to a slurry of $\mathrm{LiAlH}_{4}(2.3 \mathrm{~g}, 60.0 \mathrm{mmol})$ in $\mathrm{Et}_{2} \mathrm{O}(100 \mathrm{~mL})$, and the mixture was stirred at room temperature for $1 \mathrm{~h}$. Ethyl acetate $(5 \mathrm{~mL})$ was carefully added, water $(10 \mathrm{~mL})$ was then introduced, and the resulting suspension was filtered. The organic layer was evaporated in vacuo to give the residue, which was triturated repeatedly with $\mathrm{CH}_{2} \mathrm{Cl}_{2}$. The solution in $\mathrm{CH}_{2} \mathrm{Cl}_{2}$ was dried $\left(\mathrm{MgSO}_{4}\right)$ and filtered. The solvent was removed in vacuo to give 18 a as a white solid $(1.73 \mathrm{~g}, 62 \%)$. M.p.: $165-166^{\circ} \mathrm{C}$; IR $(\mathrm{KBr}): \tilde{v}=2935,2830,1718,1702,1609,1523,1410,1330,1160,1129$, 1108, 1069, $1058 \mathrm{~cm}^{-1} ;{ }^{1} \mathrm{H}$ NMR $\left(400 \mathrm{MHz}, \mathrm{CDCl}_{3}\right): \delta=1.52(\mathrm{~d}, J=$ $8.0 \mathrm{~Hz}, 1 \mathrm{H}), 1.62(\mathrm{~d}, J=8.0 \mathrm{~Hz}, 1 \mathrm{H}), 2.92-3.28(\mathrm{~m}, 8 \mathrm{H}), 6.16(\mathrm{~s}, 2 \mathrm{H})$, $6.42(\mathrm{~d}, \quad J=8.5 \mathrm{~Hz}, 2 \mathrm{H}), \quad 7.40 \mathrm{ppm} \quad(\mathrm{d}, J=8.5 \mathrm{~Hz}, 2 \mathrm{H}) ;{ }^{13} \mathrm{C} \mathrm{NMR}$ $\left(100 \mathrm{MHz}, \mathrm{CDCl}_{3}\right): \delta=45.4,46.6,50.4,52.1,111.0,116.5$ (q, $\left.J=32.4 \mathrm{~Hz}\right)$, 124.3 (q, $J=1074 \mathrm{~Hz}), 126.2,129.6$ (q, $J=114 \mathrm{~Hz}), 135.8,149.3$; HRMS $(\mathrm{FAB}+): m / z$ calcd for $\mathrm{C}_{16} \mathrm{H}_{16} \mathrm{~F}_{3} \mathrm{~N}: 279.1235[M]^{+}$; found: 279.1237 .

$18 \mathbf{c}$ : In a manner similar to that described for the preparation of $\mathbf{1 8} \mathbf{a}$, the reaction of $\mathrm{LiAlH}_{4}(2.3 \mathrm{~g}, 60.0 \mathrm{mmol})$ and (4-bromophenyl)-4-aza-tricyclo[5.2.1. $\left.0^{2,6}\right] \mathrm{dec}-8$-en-3,5-dione $(3.2 \mathrm{~g}, 10.0 \mathrm{mmol})$ afforded $\mathbf{1 8 c}$ as white crystals $\left(2.2 \mathrm{~g}, 77 \%\right.$ ). M.p.: $133-134^{\circ} \mathrm{C}$; IR (KBr): $\tilde{v}=2986,2956,2946$, 2874, 2844, 1594, 1498, 1473, 1374, 1344, 1255, 1200,1181, 808, $790 \mathrm{~cm}^{-1}$; ${ }^{1} \mathrm{H}$ NMR $\left(500 \mathrm{MHz}, \mathrm{CDCl}_{3}\right): \delta=1.52(\mathrm{~d}, J=8.2 \mathrm{~Hz}, 1 \mathrm{H}), 1.62(\mathrm{~d}, J=$ $8.2 \mathrm{~Hz}, 1 \mathrm{H}), 2.84-3.20(\mathrm{~m}, 8 \mathrm{H}), 6.16(\mathrm{~s}, 2 \mathrm{H}), 6.30(\mathrm{~d}, J=7.2 \mathrm{~Hz}, 2 \mathrm{H})$,
$7.25 \mathrm{ppm}(\mathrm{d}, J=7.2 \mathrm{~Hz}, 2 \mathrm{H}) ;{ }^{13} \mathrm{C} \mathrm{NMR}\left(125 \mathrm{MHz}, \mathrm{CDCl}_{3}\right): \delta=45.6,46.5$, 50.6, 52.2, 107.2, 113.4, 131.6, 135.8, 146.5 ppm; HRMS (FAB): $m / z$ calcd for $\mathrm{C}_{15} \mathrm{H}_{16}{ }^{79} \mathrm{BrN}$ : $289.0466[M]^{+}$; found: 289.0467 ; elemental analysis: calcd (\%) for $\mathrm{C}_{15} \mathrm{H}_{16} \mathrm{BrN}$ : C 62.08, $\mathrm{H}$ 5.56, N 4.83; found: $\mathrm{C} 61.87, \mathrm{H}$ $5.03, \mathrm{~N} 4.76$.

18d: In a manner similar to that described for the preparation of $\mathbf{1 8 a}$, the reaction of $\mathrm{LiAlH}_{4}(4.6 \mathrm{~g}, 120.0 \mathrm{mmol})$ and 4-phenyl-4-azatricyclo[5.2.1. $\left.0^{2,6}\right]$ dec-8-en-3,5-dione ${ }^{[21]}(4.8 \mathrm{~g}, 20.0 \mathrm{mmol})$ afforded $\mathbf{1 8 d}$ as white crystals $\left(3.2 \mathrm{~g}, 77 \%\right.$ ). M.p.: $88-89^{\circ} \mathrm{C}$ (lit.: $93-94{ }^{\circ} \mathrm{C}$ ); ${ }^{1} \mathrm{H} \mathrm{NMR}$ $\left(400 \mathrm{MHz}, \mathrm{CDCl}_{3}\right): \delta=1.50(\mathrm{~d}, J=8.2 \mathrm{~Hz}, 1 \mathrm{H}), 1.59(\mathrm{~d}, J=8.2 \mathrm{~Hz}, 1 \mathrm{H})$, 2.87-2.90 (m, 2 H), 2.96 (brs, 2H), 3.04-3.07 (m, 2 H), 3.19-3.24 (m, 2 H), $6.14(\mathrm{~s}, 2 \mathrm{H}), 6.44(\mathrm{~d}, J=8.5 \mathrm{~Hz}, 2 \mathrm{H}), 6.62(\mathrm{~m}, 1 \mathrm{H}), 7.18 \mathrm{ppm}(\mathrm{d}, J=$ $7.7 \mathrm{~Hz}, 2 \mathrm{H}) ;{ }^{13} \mathrm{C} \mathrm{NMR}(100 \mathrm{MHz}): \delta=45.5,46.5,50.5,52.2,111.9,115.4$, 129.0, 135.8, 147.7 ppm.

18 e: In a manner similar to that described for the preparation of $\mathbf{1 8 a}$, the reaction of $\mathrm{LiAlH}_{4}(2.3 \mathrm{~g}, 60.0 \mathrm{mmol})$ and 4-(4-tolyl)-(4-azatricyclo[5.2.1.0 $\left.0^{2,6}\right]$ dec-8-en-3,5-dione ${ }^{[22]}(2.5 \mathrm{~g}, 10.0 \mathrm{mmol})$ afforded $18 \mathrm{e}$ as white crystals $(1.5 \mathrm{~g}, 67 \%)$. M.p.: $103-105^{\circ} \mathrm{C}$; IR $(\mathrm{KBr}): \tilde{v}=2954,2863$, 2843, 1619, 1561, 1473, 1367, 1348, 1202, 1180, 1132, 1033, 812, 794, 735, $716 \mathrm{~cm}^{-1} ;{ }^{1} \mathrm{H}$ NMR $\left(500 \mathrm{MHz}, \mathrm{CDCl}_{3}\right): \delta=1.54(\mathrm{~d}, J=8.1 \mathrm{~Hz}, 1 \mathrm{H}), 1.62$ $(\mathrm{d}, J=8.1 \mathrm{~Hz}, 1 \mathrm{H}), 2.28(\mathrm{~s}, 3 \mathrm{H}), 2.90(\mathrm{~d}, J=9.3 \mathrm{~Hz}, 2 \mathrm{H}), 3.00(\mathrm{~s}, 2 \mathrm{H})$, 3.08 (brs, 2H), $3.24(\mathrm{t}, J=8.6 \mathrm{~Hz}, 2 \mathrm{H}), 6.18(\mathrm{~s}, 2 \mathrm{H}), 6.42(\mathrm{~d}, J=8.2 \mathrm{~Hz}$, $2 \mathrm{H}), 7.05 \mathrm{ppm}(\mathrm{d}, J=8.2 \mathrm{~Hz}, 2 \mathrm{H}) ;{ }^{13} \mathrm{C} \mathrm{NMR}\left(125 \mathrm{MHz}, \mathrm{CDCl}_{3}\right): \delta=20.3$, 45.6, 46.5, 50.8, 52.2, 112.0, 124.4, 129.6, 135.9, 145.9 ppm; HRMS $(\mathrm{FAB}+): m / z$ calcd for $\mathrm{C}_{16} \mathrm{H}_{19} \mathrm{~N}: 225.1517[M]^{+}$; found: 225.1517 ; elemental analysis: calcd (\%) for $\mathrm{C}_{16} \mathrm{H}_{19} \mathrm{~N}$ : C 85.28, H 8.50, N 6.22; found: C 85.77, H 8.43, N 6.46 .

$18 \mathrm{f}$ : In a manner similar to that described for the preparation of $\mathbf{1 8 a}$, the reaction of $\mathrm{LiAlH}_{4}(2.3 \mathrm{~g}, 60.0 \mathrm{mmol})$ and 4-(4-anisyl)-4-azatricyclo[5.2.1. $\left.0^{2,6}\right]$ dec-8-en-3,5-dione $(2.7 \mathrm{~g}, 10.0 \mathrm{mmol})$ afforded $\mathbf{1 8 \mathbf { f }}$ as white crystals $(1.5 \mathrm{~g}, 60 \%)$. M.p.: $101-103^{\circ} \mathrm{C}$; IR $(\mathrm{KBr}): \tilde{v}=2935,2830,1512$, 1479, 1440, 1364, 1334, 1280, 1240, 1180, $1054 \mathrm{~cm}^{-1} ;{ }^{1} \mathrm{H}$ NMR $(500 \mathrm{MHz}$, $\left.\mathrm{CDCl}_{3}\right): \delta=1.53(\mathrm{~d}, J=8.8 \mathrm{~Hz}, 1 \mathrm{H}), 1.62(\mathrm{~d}, J=8.8 \mathrm{~Hz}, 1 \mathrm{H}), 2.84(\mathrm{~d}, J=$ $11.5 \mathrm{~Hz}, 2 \mathrm{H}), 2.97$ (brs, 2H), 3.08 (brs, $2 \mathrm{H}), 3.22$ (t, $J=9.6 \mathrm{~Hz}, 2 \mathrm{H}), 3.76$ $(\mathrm{s}, 3 \mathrm{H}), 6.17(\mathrm{~s}, 2 \mathrm{H}), 6.45(\mathrm{~d}, J=8.8 \mathrm{~Hz}, 2 \mathrm{H}), 6.83 \mathrm{ppm}(\mathrm{d}, J=8.8 \mathrm{~Hz}$, $2 \mathrm{H}) ;{ }^{13} \mathrm{C} \mathrm{NMR}\left(125 \mathrm{MHz}, \mathrm{CDCl}_{3}\right): \delta=45.7,46.3,51.3,52.3,55.9,113.0$, $114.9,135.9,141.2,153.9 \mathrm{ppm}$; HRMS $(\mathrm{FAB}+): \mathrm{m} / \mathrm{z}$ calcd for $\mathrm{m} / \mathrm{z}$ $\mathrm{C}_{16} \mathrm{H}_{19} \mathrm{NO}: 241.1467[M]^{+}$; found: 241.1469 ; elemental analysis: calcd (\%) for $\mathrm{C}_{16} \mathrm{H}_{19} \mathrm{NO}$ : C 79.63, H 7.94, N 5.80; found: C 79.87, H 7.93, N 6.16 .

22b: 4-(4-Bromophenyl)-4-aza-exo-tricyclo[5.2.1.0 $\left.0^{2,6}\right] \mathrm{dec}-8$-ene-3,5dione ${ }^{[11 \mathrm{c}]}(14.0 \mathrm{~g}, 45 \mathrm{mmol})$ in $\mathrm{CH}_{2} \mathrm{Cl}_{2}(250 \mathrm{~mL})$ was added slowly to a suspension of $\mathrm{LiAlH}_{4}(6.80 \mathrm{~g}, 180 \mathrm{mmol})$ in $\mathrm{Et}_{2} \mathrm{O}(250 \mathrm{~mL})$, and the mixture was stirred at room temperature for $1 \mathrm{~h} . \mathrm{H}_{2} \mathrm{O}(10 \mathrm{~mL})$ and $\mathrm{NaOH}$ ( $10 \%$ in $\left.\mathrm{H}_{2} \mathrm{O}, 5 \mathrm{~mL}\right)$ were then introduced, and the resulting suspension was filtered. The residue was triturated repeatedly with $\mathrm{CH}_{2} \mathrm{Cl}_{2}$ and then filtered. The organic solution was dried $\left(\mathrm{MgSO}_{4}\right)$ and filtered. The filtrate was evaporated in vacuo to give $22 \mathbf{b}$ as a white solid $(9.70 \mathrm{~g}, 72 \%)$. M.p.: 133-134 ${ }^{\circ} \mathrm{C}$; IR (KBr): $\tilde{v}=3070,2960,2835,1590,1558,1495,1479,1366$, 1329, 1267, 1182, 811, 801, 709, $676 \mathrm{~cm}^{-1}$; ${ }^{1} \mathrm{H}$ NMR $\left(300 \mathrm{MHz}, \mathrm{CDCl}_{3}\right)$ : $\delta=1.37(\mathrm{dt}, J=9.0,1.5 \mathrm{~Hz}, 1 \mathrm{H}), 1.56(\mathrm{~d}, J=9.0 \mathrm{~Hz}, 1 \mathrm{H}), 2.38-2.41(\mathrm{~m}$, $2 \mathrm{H}), 2.72-2.74(\mathrm{~m}, 2 \mathrm{H}), 2.99(\mathrm{dd}, J=9.6,3.6 \mathrm{~Hz}, 2 \mathrm{H}), 3.32-3.42(\mathrm{~m}$, $2 \mathrm{H}), 6.16(\mathrm{~s}, 2 \mathrm{H}), 6.42(\mathrm{~d}, J=9.0 \mathrm{~Hz}, 2 \mathrm{H}, 2 \times$ phenyl-H), $7.28 \mathrm{ppm}(\mathrm{d}, J=$ $9.0 \mathrm{~Hz}, 2 \mathrm{H}) ;{ }^{13} \mathrm{C}$ NMR $\left(75 \mathrm{MHz}, \mathrm{CDCl}_{3}\right): \delta=42.4,44.5,47.6,52.9,108.0$, 114.0, 131.7, 137.7, 147.1 ppm; HRMS (MALDI): $\mathrm{m} / \mathrm{z}$ calcd for $\mathrm{C}_{15} \mathrm{H}_{16} \mathrm{BrN}+1: 290.0544$, found: 290.0539 ; elemental analysis: calcd (\%) for $\mathrm{C}_{15} \mathrm{H}_{16} \mathrm{BrN}$ : C 62.08, $\mathrm{H}$ 5.56, N 4.83; found: C 62.52, $\mathrm{H} 5.56, \mathrm{~N} 4.63$. $22 \mathrm{c}$ : $n \mathrm{BuLi}(13 \mathrm{~mL}, 2.5 \mathrm{M}$ in hexane, $30 \mathrm{mmol})$ was added dropwise under argon to a solution of $\mathbf{2 2} \mathbf{b}(5.80 \mathrm{~g}, 20 \mathrm{mmol})$ in dry THF $(140 \mathrm{~mL})$ cooled to $-78^{\circ} \mathrm{C}$. After stirring at $-78^{\circ} \mathrm{C}$ for $1 \mathrm{~h}$, excess $\mathrm{CO}_{2}$ gas was bubbled into the solution until a white solid $(\approx 2 \mathrm{~h})$ was precipitated. The mixture was gradually warmed to room temperature, poured into a mixture of $\mathrm{Et}_{2} \mathrm{O}(200 \mathrm{~mL})$ and $\mathrm{H}_{2} \mathrm{O}(200 \mathrm{~mL})$, and filtered to give the filter cake and filtrate I. The filter cake was dissolved in aq. $\mathrm{NaOH}(10 \%, 1 \mathrm{~L})$, and the solution was acidified with aq. $\mathrm{HCl}(10 \%)$ until ph 6 to give a precipitate, which was filtered. Additional solid was obtained from neutralization of filtrate I $(10 \% \mathrm{HCl}$ until ph 6$)$. The combined solid was washed with $\mathrm{Et}_{2} \mathrm{O}(2 \times 100 \mathrm{~mL})$ to give $22 \mathrm{c}$ as a white solid $(4.59 \mathrm{~g}, 90 \%)$. M.p.: $278^{\circ} \mathrm{C}$ 
(decomp.); IR (KBr): $\tilde{v}=3060,2962,2850,1664,1599,1554,1525,1477$, $1420,1384,1328,1288,1180,827,775,702,670 \mathrm{~cm}^{-1} ;{ }^{1} \mathrm{H}$ NMR $(300 \mathrm{MHz}$, [D $\mathrm{D}_{6}$ DMSO (dimethyl sulfoxide)): $\delta=1.27(\mathrm{~d}, J=9.0 \mathrm{~Hz}, 1 \mathrm{H}), 1.41(\mathrm{~d}$, $J=9.0 \mathrm{~Hz}, 1 \mathrm{H}), 2.33-2.41(\mathrm{~m}, 2 \mathrm{H}), 2.75(\mathrm{brs}, 2 \mathrm{H}), 3.06-3.10(\mathrm{~m}, 2 \mathrm{H})$, $3.39-3.50(\mathrm{~m}, 2 \mathrm{H}), 6.19(\mathrm{~s}, 2 \mathrm{H}), 6.55(\mathrm{~d}, J=9.0 \mathrm{~Hz}, 2 \mathrm{H}), 7.75(\mathrm{~d}, J=$ $9.0 \mathrm{~Hz}, 2 \mathrm{H}), 12.09 \mathrm{ppm}(\mathrm{s}, 1 \mathrm{H}) ;{ }^{13} \mathrm{C}$ NMR $\left(75 \mathrm{MHz},\left[\mathrm{D}_{6}\right] \mathrm{DMSO}\right): \delta=$ $42.4,44.3,47.5,52.6,111.8,117.5,134.0,151.1,168.0 \mathrm{ppm}$; HRMS (MALDI): $\mathrm{m} / z$ calcd for $\mathrm{C}_{16} \mathrm{H}_{18} \mathrm{NO}_{2}+1: 256.1338$; found: 256.1332 ; elemental analysis: calcd (\%) for $\mathrm{C}_{16} \mathrm{H}_{17} \mathrm{NO}_{2}$ : C 75.27, H 6.71, N 5.49; found: C 75.24, H 6.68, N 5.41.

22a: Oxalyl chloride $(7.2 \mathrm{~mL}, 80 \mathrm{mmol})$ and $N, N$-dimethylformamide (DMF; 3 drops) were added to a suspension of 22 c $(10.20 \mathrm{~g}, 40 \mathrm{mmol})$ in $\mathrm{CH}_{2} \mathrm{Cl}_{2}(150 \mathrm{~mL})$ at $0^{\circ} \mathrm{C}$. The mixture was gradually warmed to room temperature and then stirred for $3 \mathrm{~h}$. The solvent was removed in vacuo to give the corresponding acid chloride, which was dissolved in $\mathrm{CH}_{2} \mathrm{Cl}_{2}$ $(70 \mathrm{~mL}) . \mathrm{EtOH}(15 \mathrm{~mL})$ was added to this solution, and the mixture was stirred at room temperature for $5 \mathrm{~h}$. Water was introduced, and the organic layer was separated and washed with water and brine $(200 \mathrm{~mL})$ and then dried $\left(\mathrm{MgSO}_{4}\right)$. The solvent was removed in vacuo to give $22 \mathbf{a}$ as a white solid $(10.30 \mathrm{~g}, 90 \%)$. M.p.: $123-124^{\circ} \mathrm{C}$; UV/Vis $\left(\mathrm{CHCl}_{3}\right): \lambda_{\max }(\varepsilon)=$ $313 \mathrm{~nm}\left(90.8 \mathrm{~g}^{-1} \mathrm{~cm}^{2}\right)$; IR $(\mathrm{KBr}): \tilde{v}=3053,2974,2958,2875,1701,1691$, $1612,1556,1525,1473,1386,1369,1280,1181,1104,828,771,709,699$, $680 \mathrm{~cm}^{-1} ;{ }^{1} \mathrm{H}$ NMR $\left(300 \mathrm{MHz}, \mathrm{CDCl}_{3}\right): \delta=1.36(\mathrm{t}, J=7.2 \mathrm{~Hz}, 3 \mathrm{H}), 1.38$ $(\mathrm{dt}, J=9.0,1.5 \mathrm{~Hz}, 1 \mathrm{H}), 1.50(\mathrm{~d}, J=9.0 \mathrm{~Hz}, 1 \mathrm{H}), 2.41-2.44(\mathrm{~m}, 2 \mathrm{H}), 2.75$ $(\mathrm{t}, J=1.8 \mathrm{~Hz}, 2 \mathrm{H}), 3.10(\mathrm{dd}, J=10.2,2.7 \mathrm{~Hz}, 2 \mathrm{H}), 3.44-3.55(\mathrm{~m}, 2 \mathrm{H})$, $4.31(\mathrm{q}, J=7.2 \mathrm{~Hz}, 2 \mathrm{H}), 6.17(\mathrm{t}, J=1.8 \mathrm{~Hz}, 2 \mathrm{H}), 6.49(\mathrm{~d}, J=9.0 \mathrm{~Hz}, 2 \mathrm{H})$, $7.90 \mathrm{ppm}(\mathrm{d}, J=9.0 \mathrm{~Hz}) ;{ }^{13} \mathrm{C} \mathrm{NMR}\left(75 \mathrm{MHz}, \mathrm{CDCl}_{3}\right): \delta=14.5,42.3,44.3$, 47.7, 60.1, 111.2, 117.2, 131.2, 137.6, 150.9, 167.1 ppm; HRMS (MALDI): $\mathrm{m} / z$ calcd for $\mathrm{C}_{18} \mathrm{H}_{21} \mathrm{NO}_{2}+1$ : 284.1651; found: 284.1645 ; elemental analysis: calcd (\%) for $\mathrm{C}_{18} \mathrm{H}_{21} \mathrm{NO}_{2}$ : C 76.29, $\mathrm{H} \mathrm{7.47,} \mathrm{N} \mathrm{4.94;} \mathrm{found:} \mathrm{C} 76.02, \mathrm{H}$ 7.26, N 4.67 .

23 b: 4-(4-Bromophenyl)-4-aza-10-oxa-exo-tricyclo[5.2.1.0 $\left.0^{2,6}\right]$ dec-8-ene3,5-dione ${ }^{[23]}(9.60 \mathrm{~g}, 30 \mathrm{mmol})$ in $\mathrm{CH}_{2} \mathrm{Cl}_{2}(150 \mathrm{~mL})$ was added slowly to a slurry of $\mathrm{LiAlH}_{4}(6.80 \mathrm{~g}, 180 \mathrm{mmol})$ in $\mathrm{Et}_{2} \mathrm{O}(250 \mathrm{~mL})$, and the mixture was stirred at room temperature for $4 \mathrm{~h} . \mathrm{H}_{2} \mathrm{O}(21 \mathrm{~mL})$ and $\mathrm{NaOH}(10 \%$, $7 \mathrm{~mL}$ ) were then introduced, and the resulting suspension was filtered. The residue was triturated repeatedly with $\mathrm{CH}_{2} \mathrm{Cl}_{2}$ and filtered. The organic solution was dried $\left(\mathrm{MgSO}_{4}\right)$ and filtered, and the filtrate was evaporated in vacuo to give $\mathbf{2 3 b}$ as a white solid $(6.19 \mathrm{~g}, 71 \%)$. M.p.: $178-179^{\circ} \mathrm{C}$; IR (KBr): $\tilde{v}=3072,3000,2956,2830,1590,1494,1473,1369$, $1183,906,701 \mathrm{~cm}^{-1} ;{ }^{1} \mathrm{H}$ NMR $\left(300 \mathrm{MHz}, \mathrm{CDCl}_{3}\right): \delta=2.56-2.60(\mathrm{~m}, 2 \mathrm{H})$, $3.02(\mathrm{dd}, J=9.9,3.6 \mathrm{~Hz}, 2 \mathrm{H}), 3.58(\mathrm{t}, J=8.7 \mathrm{~Hz}, 2 \mathrm{H}), 4.80(\mathrm{~s}, 2 \mathrm{H}), 6.41$ $(\mathrm{s}, 2 \mathrm{H}), 6.46(\mathrm{~d}, J=8.4 \mathrm{~Hz}, 2 \mathrm{H}), 7.28 \mathrm{ppm}(\mathrm{d}, J=8.4 \mathrm{~Hz}, 2 \mathrm{H}) ;{ }^{13} \mathrm{C}$ NMR $\left(75 \mathrm{MHz}, \quad \mathrm{CDCl}_{3}\right): \delta=44.3, \quad 52.0, \quad 82.8, \quad 108.7, \quad 114.6, \quad 131.7,136.1$, $147.4 \mathrm{ppm}$; HRMS (MALDI): $\mathrm{m} / z$ calcd for $\mathrm{C}_{14} \mathrm{H}_{14} \mathrm{ONBr}+1: 292.0339$; found: 292.0332; elemental analysis: calcd (\%) for $\mathrm{C}_{14} \mathrm{H}_{14} \mathrm{BrNO}$ : C 57.55, H 4.83, N 4.79, Br 27.35; found: C 57.56, H 4.87, N 4.60, Br 27.48.

$23 \mathbf{c}$ : In a manner similar to that described for the preparation of $\mathbf{2 2} \mathbf{b}$, 23b $(5.84 \mathrm{~g}, 20 \mathrm{mmol})$ gave $23 \mathbf{c}$ as a white solid (5.0 g, 97\%). M.p.: 276$277^{\circ} \mathrm{C}$; IR (KBr): $\tilde{v}=3000,2972,2958,2861,2661,2542,1670,1600,1525$, 1477, 1437, 1420, 1382, 1319, 1290, 1181, 905, 831, $695 \mathrm{~cm}^{-1} ;{ }^{1} \mathrm{H}$ NMR (300 MHz, [D $\mathrm{D}_{6}$ DMSO): $\delta=2.52(\mathrm{t}, J=4.2,2 \mathrm{H}), 3.08-3.13(\mathrm{~m}, 2 \mathrm{H}), 3.53-$ $3.60(\mathrm{~m}, 2 \mathrm{H}), 4.82(\mathrm{~s}, 2 \mathrm{H}), 6.44(\mathrm{~s}, 2 \mathrm{H}), 6.54(\mathrm{~d}, J=8.7,2 \mathrm{H}), 7.28(\mathrm{~d}, J=$ $8.7 \mathrm{~Hz}, 2 \mathrm{H}$ ), $12.14 \mathrm{ppm}$ (s); HRMS (MALDI): $\mathrm{m} / \mathrm{z}$ calcd for $\mathrm{C}_{15} \mathrm{H}_{15} \mathrm{NO}_{3}+1$ : 258.1130; found: 258.1125 ; elemental analysis: calcd (\%) for $\mathrm{C}_{15} \mathrm{H}_{15} \mathrm{NO}_{3}$ : C 70.02, $\mathrm{H}$ 5.88, N 5.44; found: C 70.15, H 5.74, N 5.11. $\mathbf{2 3 a}$ : In a manner similar to that described for the preparation of $\mathbf{2 2} \mathbf{a}$, 23b (4.6 g, $18 \mathrm{mmol})$ gave 23 a as a white solid (4.07 g, 79\%). M.p.: 178$179^{\circ} \mathrm{C}$; UV/Vis $\left(\mathrm{CHCl}_{3}\right): \lambda_{\max }(\varepsilon)=310 \mathrm{~nm} \quad\left(81.6 \mathrm{~g}^{-1} \mathrm{~cm}^{2}\right) ;{ }^{1} \mathrm{H} \mathrm{NMR}$ $\left(300 \mathrm{MHz}, \mathrm{CDCl}_{3}\right): \delta=1.29(\mathrm{t}, J=7.2 \mathrm{~Hz}, 3 \mathrm{H}), 2.51-2.55(\mathrm{~m}, 2 \mathrm{H}), 3.08-$ $3.13(\mathrm{~m}, 2 \mathrm{H}), 3.56-3.60(\mathrm{~m}, 2 \mathrm{H}), 4.24(\mathrm{q}, J=7.2 \mathrm{~Hz}, 2 \mathrm{H}), 4.75(\mathrm{~s}, 2 \mathrm{H})$, $6.34(\mathrm{~s}, 2 \mathrm{H}), 6.46(\mathrm{~d}, J=8.7 \mathrm{~Hz}, 2 \mathrm{H}), 7.83 \mathrm{ppm}(\mathrm{d}, J=8.7 \mathrm{~Hz}, 2 \mathrm{H})$; ${ }^{13} \mathrm{C}$ NMR $\left(75 \mathrm{MHz}, \mathrm{CDCl}_{3}\right): \delta=14.5,44.2,51.6,60.2,83.1,111.6,117.6$, 131.2, 136.1, 151.0, $167.1 \mathrm{ppm}$; HRMS (MALDI): $\mathrm{m} / \mathrm{z}$ calcd for $\mathrm{C}_{17} \mathrm{H}_{19} \mathrm{NO}_{3}+1$ : 286.1440; found: 286.1438 ; elemental analysis: calcd (\%) for $\mathrm{C}_{17} \mathrm{H}_{19} \mathrm{NO}_{3}$ : C 71.56, H 6.71, N 4.91; found: C 71.55, H 6.68, N 4.76. 17a: A solution of $\mathbf{1 8 a}(307 \mathrm{mg}, 1.1 \mathrm{mmol})$ and $\mathbf{1}(41 \mathrm{mg}, 0.05 \mathrm{mmol})$ in $\mathrm{CH}_{2} \mathrm{Cl}_{2}(3.6 \mathrm{~mL})$ was stirred under argon at room temperature for
$30 \mathrm{~min}$, quenched with ethyl vinyl ether $(1 \mathrm{~mL})$, and poured into $\mathrm{MeOH}$ $(20 \mathrm{~mL})$. The solid was collected, redissolved in $\mathrm{CHCl}_{3}(1 \mathrm{~mL})$, and reprecipitated by adding $\mathrm{MeOH}(20 \mathrm{~mL})$. This procedure was repeated two or three times, and 17a was collected as a grayish-white solid. (250 mg, $83 \%$ ): IR (KBr): $\tilde{v}=2939,2856,1614,1530,1480,1372,1300,1224,1157$, 1006, 1068, 963, $817 \mathrm{~cm}^{-1}$; ${ }_{1}^{1} \mathrm{H}$ NMR $\left(500 \mathrm{MHz}, \mathrm{CDCl}_{3}\right): \delta=1.37$ (br, $\left.1 \mathrm{H}\right)$, 1.74 (br, $1 \mathrm{H}), 2.70-3.07$ (m, 8H), 5.38 (br, 2H), 6.36 (br, 2H), $7.20 \mathrm{ppm}$ (br, $2 \mathrm{H}) ;{ }^{13} \mathrm{C} \mathrm{NMR}\left(125 \mathrm{MHz}, \mathrm{CDCl}_{3}\right): \delta=35.63,36.12,44.6,46.3,49.6$, $111.8,116.8,126.0,126.2,131.7,150.0 \mathrm{ppm}$; GPC $(\mathrm{THF}): M_{\mathrm{n}}=10800$, $\mathrm{PDI}=1.22$; elemental analysis: calcd (\%) for $\mathrm{C}_{16} \mathrm{H}_{16} \mathrm{~F}_{3} \mathrm{~N}$ : C 68.80, H 5.77, N 5.01; found: C 68.33, H 6.03, N 5.01.

17c: In a manner similar to that described for the preparation of $17 \mathbf{a}$ 17c was obtained as a white solid $(253 \mathrm{mg}, 86 \%)$. IR (KBr): $\tilde{v}=2986$, 2874, 1594, 1498, 1473, 1374, 1344, 1183, 967, $808 \mathrm{~cm}^{-1} ;{ }^{1} \mathrm{H}$ NMR $\left(500 \mathrm{MHz}, \mathrm{CDCl}_{3}\right): \delta=1.40(\mathrm{br}, 1 \mathrm{H}), 1.77(\mathrm{br}, 1 \mathrm{H}), 2.73-3.10(\mathrm{~m}, 8 \mathrm{H})$, 5.40 (br, 2H), 6.39 (br, 2H), $7.20 \mathrm{ppm}$ (br, 2H); ${ }^{13} \mathrm{C}$ NMR (125 MHz): $\delta=35.6,35.8,44.6,46.4,50.1,108.2,114.5,130.8,131.7,147.2 \mathrm{ppm}$; GPC (THF): $M_{\mathrm{n}}=10300, \quad \mathrm{PDI}=1.09$; elemental analysis: calcd $(\%)$ for $\mathrm{C}_{15} \mathrm{H}_{16} \mathrm{BrN}$ : C 66.08, H 5.56, N 4.83; found: C 66.16, H 5.56, N 4.90.

17 d: In a manner similar to that described for the preparation of $\mathbf{1 7} \mathbf{a}$ 17d was obtained as a white solid $(269 \mathrm{mg}, 95 \%)$. IR $(\mathrm{KBr}): \tilde{v}=2990$, 2866, 1594, 1498, 1477, 1394, 1364, 1185, 966, 910, $814 \mathrm{~cm}^{-1} ;{ }^{1} \mathrm{H}$ NMR $\left(500 \mathrm{MHz}, \mathrm{CDCl}_{3}\right): \delta=1.46(\mathrm{br}, 1 \mathrm{H}), 1.76(\mathrm{br}, 1 \mathrm{H}), 2.70-3.48(\mathrm{~m}, 8 \mathrm{H})$, 5.46 (br, 2H), 6.67 (br, 3H), $7.20 \mathrm{ppm}$ (br, 2H); ${ }^{13} \mathrm{C} \mathrm{NMR}(125 \mathrm{MHz}$, $\left.\mathrm{CDCl}_{3}\right): \delta=35.8,44.8,46.4,50.2,113.1,116.5,129.0,131.5,148.6 \mathrm{ppm}$; GPC $(\mathrm{THF}): M_{\mathrm{n}}=9200, \mathrm{PDI}=1.44$; elemental analysis: calcd $(\%)$ for $\mathrm{C}_{15} \mathrm{H}_{17} \mathrm{~N}$ : C 85.26, H 8.11, N 6.63; found: C 84.32, H 8.69, N 6.02.

17e: In a manner similar to that described for the preparation of $\mathbf{1 7} \mathbf{a}$, 17 e was obtained as a white solid $(110 \mathrm{mg}, 90 \%)$. IR $(\mathrm{KBr}): \tilde{v}=2935$, 2829, 1512, 1479, 1440, 1364, 1334, 1280, 1240, 1179, 1039, 966, $814 \mathrm{~cm}^{-1}$; ${ }^{1} \mathrm{H}$ NMR $\left(500 \mathrm{MHz}, \mathrm{CDCl}_{3}\right): \delta=1.48(\mathrm{br}, 1 \mathrm{H}), 1.73(\mathrm{br}, 1 \mathrm{H}), 2.23(\mathrm{~s}$, $3 \mathrm{H}), 2.70-3.10(\mathrm{~m}, 8 \mathrm{H}), 5.49$ (br, 2H), 6.55 (br, 2H), $7.00 \mathrm{ppm}(\mathrm{br}, 2 \mathrm{H})$; ${ }^{13} \mathrm{C}$ NMR (125 MHz $\mathrm{CDCl}_{3}$ ): $\delta=20.0,35.9,45.0,46.1,50.1,112.0,124.4$, 129.0, 131.2, $147.3 \mathrm{ppm}$; GPC (THF): $M_{\mathrm{n}}=10800, \mathrm{PDI}=1.22$; elemental analysis: calcd (\%) for $\mathrm{C}_{16} \mathrm{H}_{19} \mathrm{NO}$ : C 85.28, H 8.50, N 6.22; found: C 85.65, H 8.16, N 5.99 .

17f: In a manner similar to that described for the preparation of $\mathbf{1 7 a}$, $17 \mathrm{f}$ was obtained as a white solid (132 mg, $91 \%)$. IR (KBr): $\tilde{v}=2915$, 2819, 1500, 1421, 1364, 1334, 1280, 1227, 1221, 1179, 1033, 960, $803 \mathrm{~cm}^{-1}$; ${ }^{1} \mathrm{H}$ NMR $\left(500 \mathrm{MHz}, \mathrm{CDCl}_{3}\right): \delta=1.48(\mathrm{br}, 1 \mathrm{H}), 1.73(\mathrm{br}, 1 \mathrm{H}), 2.70-3.14$ $(\mathrm{m}, 8 \mathrm{H}), 3.71(\mathrm{~s}, 3 \mathrm{H}), 5.50(\mathrm{br}, 2 \mathrm{H}), 6.55$ (br, 2H), $6.77 \mathrm{ppm}(\mathrm{br}, 2 \mathrm{H})$; ${ }^{13} \mathrm{C}$ NMR $\left(125 \mathrm{MHz}, \mathrm{CDCl}_{3}\right): \delta=35.7,45.0,46.3,51.4,55.7,114.6,114.7$, 131.4, 143.8, $151.6 \mathrm{ppm}$; GPC (THF): $M_{\mathrm{n}}=10500$, PDI =1.23; elemental analysis: calcd (\%) for $\mathrm{C}_{16} \mathrm{H}_{19} \mathrm{NO}$ : C 79.63, H 7.94, N 5.8; found: C 78.65, H 8.16, N 5.91 .

19a: A solution of $17 \mathbf{a}(200 \mathrm{mg}, 0.7 \mathrm{mmol})$ and $p$-tosylhydrazide $(2 \mathrm{~g}$, $10.9 \mathrm{mmol})$ in $\mathrm{PhCl}(10 \mathrm{~mL})$ was stirred under argon at $120^{\circ} \mathrm{C}$ for $2 \mathrm{~h}$ and filtered. The hot filtrate was poured into methanol $(50 \mathrm{~mL})$. The mixture was centrifuged to collect the precipitate, which was washed several times with methanol and dried under vacuum to yield 19a (90 mg, 45\%) as a solid. IR $(\mathrm{KBr}): \tilde{v}=2924,1770,1707,1700,1596,1500,1455,1375$, 1320, 1177, $1020 \mathrm{~cm}^{-1}$; ${ }^{1} \mathrm{H}$ NMR $\left(500 \mathrm{MHz}, \mathrm{CDCl}_{3}\right): \delta=0.99-1.96(\mathrm{~m}$, $8 \mathrm{H}), 2.86$ (br, 2H), 3.20 (br, 4H), 4.27 (br, 2H), 6.59 (br, 2H), $7.41 \mathrm{ppm}$ (br, $2 \mathrm{H}) ;{ }^{13} \mathrm{C} \mathrm{NMR}\left(125 \mathrm{MHz}, \mathrm{CDCl}_{3}\right): \delta=30.7,37.0,41.6,45.1,48.7$, $111.7,124.3,126.3,131.6,149.3 \mathrm{ppm}$; elemental analysis: calcd (\%) for $\mathrm{C}_{16} \mathrm{H}_{18} \mathrm{~F}_{3} \mathrm{~N}$ : C 68.31, H 6.45, N 4.98; found: C 67.78, H 6.64, N 4.99.

$19 \mathbf{c}$ : In a manner similar to that described for the preparation of $19 \mathbf{a}$, 17 c was obtained as a white solid $(300 \mathrm{mg}, 60 \%)$. IR $(\mathrm{KBr}): \tilde{v}=2929$, 2930, 2860, 1600, 1566, 1505, 1477, 1371, 1200, 1156, 900, 740, $725 \mathrm{~cm}^{-1}$; ${ }^{1} \mathrm{H}$ NMR $\left(500 \mathrm{MHz}, \mathrm{CDCl}_{3}\right): \delta=0.91-1.92(\mathrm{~m}, 8 \mathrm{H}), 2.82-3.15(\mathrm{~m}, 6 \mathrm{H})$, 6.67 (br, $2 \mathrm{H}), 7.20 \mathrm{ppm}(\mathrm{br}, 3 \mathrm{H}) ;{ }^{13} \mathrm{C} \mathrm{NMR}\left(100 \mathrm{MHz}, \mathrm{CDCl}_{3}\right): \delta=30.6$, 37.0, 41.8, 45.0, 49.4, 108.4, 114.7, 131.7, $147.3 \mathrm{ppm}$; elemental analysis: calcd (\%) for $\mathrm{C}_{15} \mathrm{H}_{18} \mathrm{BrNO}$ : C 61.25, $\mathrm{H}$ 6.21, N 4.79; found: $\mathrm{C} 61.45, \mathrm{H}$ 6.42 , N 5.02 .

19d: In a manner similar to that described for the preparation of $19 \mathbf{a}$, 17d was obtained as a white solid $(390 \mathrm{mg}, 63 \%)$. IR $(\mathrm{KBr}): \tilde{v}=2924$, 2933, 2750, 1620,1596, 1497, 1377, 1209, 1166, 900,900, $740 \mathrm{~cm}^{-1}$; ${ }^{1} \mathrm{H}$ NMR $\left(500 \mathrm{MHz}, \mathrm{CDCl}_{3}\right): \delta=0.95(\mathrm{br}, 1 \mathrm{H}), 1.23-1.95(\mathrm{~m}, 7 \mathrm{H}), 2.83-$ 
$3.21(\mathrm{~m}, 6 \mathrm{H}), 6.67(\mathrm{br}, 3 \mathrm{H}), 7.20 \mathrm{ppm}(\mathrm{br}, 2 \mathrm{H}) ;{ }^{13} \mathrm{C} \mathrm{NMR}(125 \mathrm{MHz}$, $\left.\mathrm{CDCl}_{3}\right): \delta=30.5,37.0,42.1,45.0,49.4,113.4,116.7,129.0,148.7 \mathrm{ppm}$; elemental analysis: calcd (\%) for $\mathrm{C}_{15} \mathrm{H}_{19} \mathrm{~N}$ : C 84.46, H 8.98, N 6.57; found: C 84.67, H 8.68, N 6.47.

19e: In a manner similar to that described for the preparation of $19 \mathbf{a}$ 17e was obtained as a white solid $(150 \mathrm{mg}, 55 \%)$. IR $(\mathrm{KBr}): \tilde{v}=2917$, 2854, 1619, 1519, 1478, 1363, 1334, 1166, $802 \mathrm{~cm}^{-1}$; ${ }^{1} \mathrm{H}$ NMR $(500 \mathrm{MHz}$, $\left.\mathrm{CDCl}_{3}\right): \delta=0.91-1.88(\mathrm{~m}, 8 \mathrm{H}), 2.33(\mathrm{~s}, 3 \mathrm{H}), 2.78-3.14(\mathrm{~m}, 6 \mathrm{H}), 6.57(\mathrm{br}$, $2 \mathrm{H}), 7.00 \mathrm{ppm}(\mathrm{br}, 2 \mathrm{H}) ;{ }^{13} \mathrm{C}$ NMR $\left(125 \mathrm{MHz}, \mathrm{CDCl}_{3}\right): \delta=20.3,30.5$, 36.9, 37.0, 42.4, 44.9, 49.8, 113.6, 125.7, 129.5, 146.9 ppm; elemental analysis: calcd (\%) for $\mathrm{C}_{16} \mathrm{H}_{21} \mathrm{~N}$ : C 84.53, $\mathrm{H}$ 9.31, N 6.16; found: $\mathrm{C} 84.98, \mathrm{H}$ 9.59, N 6.01 .

19f: In a manner similar to that described for the preparation of 19a, $19 \mathrm{f}$ was obtained as a white solid $(290 \mathrm{mg}, 59 \%)$. IR $(\mathrm{KBr}): \tilde{v}=2944$, 2963, 2829, 1600, 1519, 1478, 1363, 1334, 1166, $802 \mathrm{~cm}^{-1}$; ${ }^{1} \mathrm{H}$ NMR $\left(500 \mathrm{MHz}, \mathrm{CDCl}_{3}\right): \delta=0.97(\mathrm{br}, 1 \mathrm{H}), 1.34-1.93(\mathrm{~m}, 5 \mathrm{H}), 2.84-3.18(\mathrm{~m}$, $6 \mathrm{H}), 3.74$ (s, $3 \mathrm{H}), 6.67$ (br, $2 \mathrm{H}), 6.83 \mathrm{ppm}(\mathrm{br}, 2 \mathrm{H}) ;{ }^{13} \mathrm{C} \mathrm{NMR}(125 \mathrm{MHz}$, $\left.\mathrm{CDCl}_{3}\right): \delta=30.5,36.95,37.03,42.4,45.0,50.5,55.8,114.7,114.8,144.0$

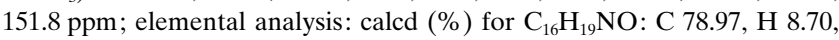
$\mathrm{N}$ 6.57; found: C 79.55, H 8.90, N 6.98 .

20: In a manner similar to that described for the preparation of $19 \mathbf{a}$, reaction of 22 a $(566 \mathrm{mg}, 2 \mathrm{mmol})$ and $\left[\left(\mathrm{Cy}_{3} \mathrm{P}\right)_{2} \mathrm{Cl}_{2} \mathrm{Ru}=\mathrm{CHPh}\right](41 \mathrm{mg}$, $0.05 \mathrm{mmol})$ in $\mathrm{CH}_{2} \mathrm{Cl}_{2}(20 \mathrm{~mL})$ gave 20 as a white solid $(417 \mathrm{mg}, 74 \%)$. UV/Vis $\left(\mathrm{CHCl}_{3}\right): \lambda_{\max }(\varepsilon)=309 \mathrm{~nm}\left(89.9 \mathrm{~g}^{-1} \mathrm{~cm}^{2}\right)$; IR $(\mathrm{KBr}): \tilde{v}=3053$, 2974, 2931, 2848, 1702, 1607, 1560, 1522, 1478, 1381, 1365, 1276, 1180, 1103, 964, 829, 769, $698 \mathrm{~cm}^{-1} ;{ }^{1} \mathrm{H}$ NMR $\left(300 \mathrm{MHz}, \mathrm{CDCl}_{3}\right): \delta=1.37$ (brt, $J=7.2 \mathrm{~Hz}, 3 \mathrm{H}), 1.44$ (br, $1 \mathrm{H}), 2.02$ (br, $1 \mathrm{H}), 2.37$ (br, $2 \mathrm{H}), 2.55$ (br, $2 \mathrm{H}$ ), 3.36 (br, 4H), 4.33 (brq, $J=7.2 \mathrm{~Hz}, 2 \mathrm{H}$ ), 5.37 (br, $0.55 \mathrm{H}$, cis double bond), 5.48 (brs, $1.40 \mathrm{H}$, trans double bond), 6.50-6.62 (m, $2 \mathrm{H}), 7.85-$ $7.94 \mathrm{ppm}(\mathrm{m}, 2 \mathrm{H})$; GPC (THF): $M_{\mathrm{n}}=41700$, PDI $=1.39$; elemental analysis: calcd (\%) for $\left(\mathrm{C}_{18} \mathrm{H}_{21} \mathrm{NO}_{2}\right)_{n}: \mathrm{C} 76.29, \mathrm{H} \mathrm{7.47,} \mathrm{N} 4.94$; found: C 76.37, H 7.43, N 4.59. With a different amount of catalyst, 20 of other $M_{\mathrm{n}}$ values $(8500,16900)$ were obtained, and $\varepsilon$ values were 89.2 and $90.4 \mathrm{~g}^{-1} \mathrm{~cm}^{2}$, respectively.

21: In a manner similar to that described for the preparation of $19 \mathbf{a}$, reaction of $\mathbf{2 3 a}(570 \mathrm{mg}, 2 \mathrm{mmol})$ and $\left[\left(\mathrm{Cy}_{3} \mathrm{P}\right)_{2} \mathrm{Cl}_{2} \mathrm{Ru}=\mathrm{CHPh}\right] \quad(122 \mathrm{mg}$, $0.15 \mathrm{mmol})$ in $\mathrm{CH}_{2} \mathrm{Cl}_{2}(20 \mathrm{~mL})$ gave 21 as a white solid $(506 \mathrm{mg}, 88 \%)$. UV/Vis $\lambda_{\max }(\varepsilon)=309 \mathrm{~nm}\left(81.8 \mathrm{~g}^{-1} \mathrm{~cm}^{2}\right) ;{ }^{1} \mathrm{H}$ NMR $\left(300 \mathrm{MHz}, \mathrm{CDCl}_{3}\right): \delta=$ $1.29-1.40(\mathrm{~m}, 3 \mathrm{H}), 2.75-2.83(\mathrm{~m}, 2 \mathrm{H}), 3.16-3.61(\mathrm{~m}, 4 \mathrm{H}), 4.13-4.36(\mathrm{~m}$, $2 \mathrm{H}), 4.44$ (brs, 2H), 5.75-6.00 (m, 2H), 6.40-6.61 (m, 2H), 7.82$7.97 \mathrm{ppm}(\mathrm{m}, 2 \mathrm{H})$; GPC (THF): $M_{\mathrm{n}}=4100, \mathrm{PDI}=1.14$; elemental analysis: calcd (\%) for $\left(\mathrm{C}_{17} \mathrm{H}_{19} \mathrm{NO}_{3}\right)_{n}$ : C 71.56, $\mathrm{H}$ 6.71, $\mathrm{N}$ 4.91; found: $\mathrm{C} 71.42$, $\mathrm{H}$ 6.83, N 4.62. When $10 \mathrm{~mol} \%$ of the catalyst was used, 21 with $M_{\mathrm{n}}=$ 3800 , PDI $=1.12$ was obtained, and $\varepsilon$ was $79.1 \mathrm{~g}^{-1} \mathrm{~cm}^{2}$ at $\lambda_{\max }=307 \mathrm{~nm}$.

\section{Acknowledgements}

This work was supported by the National Science Council (Taiwan), National Taiwan University, and the Shanghai Institute of Organic Chemistry.

[1] C. Yang, S.-Y. Lin, H.-C. Yang, C.-L. Lin, L. Tsai, S.-L. Huang, IW. P. Chen, C.-h. Chen, B.-Y. Jin, T.-Y. Luh, Angew. Chem. 2006, 118, 740; Angew. Chem. Int. Ed. 2006, 45, 726.

[2] The numbering of the monomeric unit in the polynorbornene backbone used in this paper are based on the numbering of norbornenes.

[3] a) J. A. Sattigeri, C.-W. Shiau, C.-C. Hsu, F.-F. Yeh, S. Liou, B.-Y. Jin, T.-Y. Luh, J. Am. Chem. Soc. 1999, 121, 1607; b) W.-Y. Lin, M. G. Murugesh, S. Sudhakar, H.-C. Yang, H.-C. Tai, C.-S. Chang, Y.-H. Liu, Y. Wang, I-W. P. Chen, C.-h. Chen, T.-Y. Luh, Chem. Eur. J. 2006, 12, 324

[4] J. G. Hamilton in Handbook of Metathesis, Vol.3 (Ed.: R. H. Grubbs), Wiley-VCH, Weinheim, 2003, pp. 143-179.

[5] K. J. Ivin, J. C. Mol, Olefin Metathesis and Metathesis Polymerization, Academic Press, San Diego, 1994.
[6] M. R. Buchmeiser, Chem. Rev. 2000, 100, 1565.

[7] a) K. J. Ivin, G. Lapienis, J. J. Rooney, Polymer 1980, 21, 436; b) H. T. Ho, K. J. Ivin, J. J. Rooney, Makromol. Chem. 1982, 183, 1629; c) J .C. Hamilton, Polymer 1998, 39, 1669; d) K. J. Ivin, A. M. Kenwright, G. E. Hofmeister, D. H. McConville, R. R. Schrock, V. Amir-Ebrahimi, A. G. Carvill, J. G. Hamilton, J. J. Rooney, Macromol. Chem. Phys. 1998, 199, 547; e) A. G. Carvill, R. M. E. Greene, J. G. Hamilton, K. J. Ivin, A. M. Kenwright, J. J. Rooney, Macromol. Chem. Phys. 1998, 199, 687.

[8] a) L. Delaude, A. Demonceau, A. F. Noels, Macromolecules 1999 , 32, 2091; b) L. Delaude, A. Demonceau, Macromolecules 2003, 36, 1446.

[9] D. M. Walba, P. Keller, R. Shao, N. A. Clark, M. Hillmyer, R. H. Grubbs, J. Am. Chem. Soc. 1996, 118, 274.

[10] a) K. J. Ivin, G. Lapienis, J. J. Rooney, Polymer 1980, 21, 436; b) H. T. Ho, K. J. Ivin, J. J. Rooney, Makromol. Chem. 1982, 183, 1629; c) J. C. Hamilton, Polymer 1998, 39, 1669; d) K. J. Ivin, A. M. Kenwright, G. E. Hofmeister, D. H. McConville, R. R. Schrock, V. Amir-Ebrahimi, A. G. Carvill, J. G. Hamilton, J. J. Rooney, Macromol. Chem. Phys. 1998, 199, 547; e) A. G. Carvill, R. M. E. Greene, J. G. Hamilton, K. J. Ivin, A. M. Kenwright, J. J. Rooney, Macromol. Chem. Phys. 1998, 199, 687.

[11] a) E. Khosravi, W. J. Feast, A. A. Al-Hajaji, T. Leejarkpai, J. Mol. Catal. A 2000, 160, 1; b) D. Wang, L. Yang, U. Decker, M. Findeisen, M. R. Buchmeiser, Macromol. Rapid Commun. 2005, 26, 1757; c) J. Asrar, Macromolecules 1994, 27, 4036.

[12] N.-T. Lin, S.-Y. Lin, S.-L. Lee, C.-h. Chen, C.-H. Hsu, L.-P. Hwang, Z.-Y. Xie, C.-H. Chen, S.-L. Huang, T.-Y. Luh, Angew. Chem. 2007; Angew. Chem. Int. Ed. 2007, in print.

[13] a) M. Kauranen, T. Verbiest, C. Boutton, M. N. Teerenstra, K. Clays, A. J. Schouten, R. J. M. Nolte, A. Persoons, Science 1995, 270, 965; b) T. Verbiest, C. Samyn, C. Boutton, S. Houbrechts, M. Kauranen, A. Persoons, Adv. Mater. 1996, 8, 756; c) T. Verbiest, S. Houbrechts, M. Kauranen, K. Clays, A. Persoons, J. Mater. Chem. 1997, 7, 2175; d) M. N. Teerenstra, J. G. Hagting, G. T. Oostergetel, A. J. Schouten, M. A. C. Devillers, R. J. M. Nolte, Thin Solid Films 1994, 248; e) J. L. Oudar, D. S. Chemla, J. Chem. Phys. 1977, 66, 2664; f) J. L. Oudar, J. Chem. Phys. 1977, 67, 446.

[14] a) M. Brake, V. Böhmer, P. Kràmer, W. Vogt, R. Wortmann, Supramol. Chem. 1993, 2, 65; b) P. J. A. Kenis, O. F. J. Noordman, S. Houbrechts, G. J. van Hummel, S. Harkema, F. C. J. M. van Veggel, K. Clays, J. F. J. Engbersen, A. Persoons, N. F. van Hulst, D. N. Reinhoudt, J. Am. Chem. Soc. 1998, 120, 7875; c) X. Yang, D. McBranch, D. Swanson, B. Li, Angew. Chem. 1996, 108, 572; Angew. Chem. Int. Ed. Engl. 1996, 35, 538; d) F. Vocanson, P. Seigle-Ferrand, R. Lamartine, A. Fort, W. Coleman, P. Shahgaldian, J. Mugnier, A. Zerroukhi, J. Mater. Chem. 2003, 13, 1596; e) G.-Y. Lu, W. Song, M.-H. Liu, F. Liu, C.-M. Jin, Chin. J. Chem. 2001, 19, 61; f) C. Hennrich, M. T. Murrillo, P. Prados, K. Song, I. Asselberghs, K. Clays, A. Persoons, J. Bebet-Buchholz, J. D. Mendoza, Chem. Commun. 2005, 2747.

[15] Attempts to obtain single crystals of $\mathbf{1 1 a}$ or $\mathbf{1 1 b}$ for X-ray analysis were unsuccessful.

[16] Because of the overlapping absorption bands for $\mathbf{1 7 b}$ and $\mathbf{1 8 b}$, the $\varepsilon_{\mathrm{d}}$ values for these substrates were not used for comparison with other polymers $\mathbf{1 7}$ and monomers $\mathbf{1 8}$ containing other substituents.

[17] C. Hansch, A. Leo, R. W. Taft, Chem. Rev. 1991, 91, 165.

[18] a) S. K. Burley, G. A. Petsko, Adv. Protein Chem. 1988, 39, 125; b) C. A. Hunter, J. Singh, J. M. Thornton, J. Mol. Biol. 1991, 218 837; c) G. R. Desiraju, A. Gavezzotti, J. Chem. Soc. Chem. Commun. 1989, 621; d) G. R. Desiraju, Crystal Engineering: The Design of Organic Solids, Elsevier, New York, 1989; e) B. M. Holligan, J. C. Jeffrey, M. D. Ward, J. Chem. Soc. Dalton Trans. 1992, 23, 3337; f) P. W. Carter, S. G. Dimagno, J. D. Porter, A. Streitwieser, J. Phys. Chem. 1993, 97, 1085; g) R. H. Grubbs, D. Kratz, Chem. Ber. 1993, 126, 149; h) M. Flock, M. Nieger, E. Breitmaier, Liebigs Ann. Chem. 1993, 4, 451; i) K. Takimiya, A. Ohnishi, Y. Aso, T. Otsubo, F. Ogura, K. Kawabata, K. Tanaka, M. Mizutani, Bull. Chem. Soc. Jpn. 1994, 67, 766; j) K. Miyamura, A. Mihara, T. Fujii, Y. Gohshi, Y. 
Ishii, J. Am. Chem. Soc. 1995, 117, 2377; k) E. E. Tucker, S. D. Christian, J. Phys. Chem. 1979, 83, 426; 1) G. Ravishanker, D. L. Beverridge, J. Am. Chem. Soc. 1985, 107, 2565; m) W. L. Jorgensen, D. L. Severance, J. Am. Chem. Soc. 1990, 112, 4768; n) J. A. Tucker, K. N. Houk, B. M. Trost, J. Am. Chem. Soc. 1990, 112, 5465; o) P. Linse, J. Am. Chem. Soc. 1992, 114, 4366; p) P. Leighton, J. A. Cowan, R. J. Abraham, J. K. Sanders, J. Org. Chem. 1988, 53, 733; q) C. A. Hunter, J. K. M. Sanders, J. Am. Chem. Soc. 1990, 112, 5525; r) C. A. Hunter, M. N. Meah, J. K. M. Sanders, J. Am. Chem. Soc. 1990, 112, 5773; s) H. L. Anderson, C. A. Hunter, M. N. Meah, J. K. M. Sanders, J. Am. Chem. Soc. 1990, 112, 5780; t) C. A. Hunter, Chem. Soc. Rev. 1994, 23, 101; u) E. M. Duffy, W. L. Jorgensen, J. Am. Chem. Soc. 1994, 116, 6337; v) Y. Kurita, C. Takayama, S. Tanaka, J. Comput. Chem. 1995, 16, 131; w) R. Laatikainen, J. Ratilainen, R. Sebastian, H. Santa, J. Am. Chem. Soc. 1995, 117, 11006.
[19] a) W. Zhang, J. S. Moore, Angew. Chem. 2006, 118, 4524; Angew. Chem. Int. Ed. 2006, 45, 4416; b) A. S. Shetty, J. Zhang, J. S. Moore, J. Am. Chem. Soc. 1996, 118, 1019; c) J. Zhang, J. S. Moore, J. Am. Chem. Soc. 1994, 116, 2655.

[20] Y. Mori, T. Fujiwara, K. Sugimoto (Toray Industries, Inc.), PCT Int. Appl., 2001, 59 [Chem. Abstr. 2001, 135, 242695].

[21] M. Augustin, M. Koehler, M. Haertling, J. Prakt. Chem. 1973, 315, 717.

[22] D. S. Andrade, E. Evilazio, Synth. Commun. 2004, 34, 3073.

[23] M. Augustin, M. Köhler, S. Härtling, J. Prakt. Chem. 1973, 315, 717.

Received: January 15, 2007 Published online: April 26, 2007 